\title{
Synthesis of Cyclic Hemiketals and Spiroketals from Dioxanorbornanes
}

\author{
Jeffrey D. Winkler and Peter J. Mikochik \\ Department of Chemistry, University of Pennsylvania, Philadelphia, PA 19104 \\ winkler@sas.upenn.edu
}

\section{Supporting Information \\ Table of Contents:}

Experimental Section

S4-S10

HR Mass Report of 5

${ }^{1} \mathrm{H}$ NMR Spectrum of 5

${ }^{13} \mathrm{C}$ NMR Spectrum of 5

S13

IR Spectrum of 5

S14

HR Mass Report of 6

S15

${ }^{1} \mathrm{H}$ NMR Spectrum of 6

S16

${ }^{13} \mathrm{C}$ NMR Spectrum of 6

S17

IR Spectrum of 6

S18

HR Mass Report of 7

${ }^{1} \mathrm{H}$ NMR Spectrum of 7

${ }^{13} \mathrm{C}$ NMR Spectrum of 7

S21 
$\begin{array}{lr}\text { IR Spectrum of } 7 & \text { S22 }\end{array}$

$\begin{array}{ll}\text { HR Mass Report of } 10 & \text { S23 }\end{array}$

$\begin{array}{ll}{ }^{1} \mathrm{H} \text { NMR Spectrum of } 10 & \text { S24 }\end{array}$

$\begin{array}{ll}{ }^{13} \text { C NMR Spectrum of } 10 & \text { S25 }\end{array}$

$\begin{array}{lr}\text { IR Spectrum of } 10 & \text { S26 }\end{array}$

$\begin{array}{ll}\text { HR Mass Report of } 12 & \text { S27 }\end{array}$

$\begin{array}{lr}{ }^{1} \mathrm{H} \text { NMR Spectrum of } 12 & \text { S28 }\end{array}$

$\begin{array}{lr}{ }^{13} \text { C NMR Spectrum of } 12 & \text { S29 }\end{array}$

$\begin{array}{lr}\text { IR Spectrum of } 12 & \text { S30 }\end{array}$

$\begin{array}{ll}\text { HR Mass Report of } 13 & \text { S31 }\end{array}$

$\begin{array}{ll}{ }^{1} \mathrm{H} \text { NMR Spectrum of } 13 & \text { S32 }\end{array}$

${ }^{13}$ C NMR Spectrum of $13 \quad$ S33

$\begin{array}{ll}\text { IR Spectrum of } 13 & \text { S34 }\end{array}$

$\begin{array}{ll}\text { HR Mass Report of } 14 & \text { S35 }\end{array}$

${ }^{1} \mathrm{H}$ NMR Spectrum of $14 \quad$ S36

$\begin{array}{ll}{ }^{13} \text { C NMR Spectrum of } 14 & \text { S37 }\end{array}$

$\begin{array}{lr}\text { IR Spectrum of } 14 & \text { S38 }\end{array}$

$\begin{array}{lr}\text { HR Mass Report of } 15 & \text { S39 }\end{array}$

$\begin{array}{ll}{ }^{1} \mathrm{H} \text { NMR Spectrum of } 15 & \text { S40 }\end{array}$

${ }^{13}$ C NMR Spectrum of $15 \quad$ S41

$\begin{array}{lr}\text { IR Spectrum of } 15 & \text { S42 }\end{array}$

$\begin{array}{ll}\text { HR Mass Report of } 17 & \text { S43 }\end{array}$

${ }^{1} \mathrm{H}$ NMR Spectrum of $17 \quad$ S44 
${ }^{13}$ C NMR Spectrum of $17 \quad$ S45

$\begin{array}{ll}\text { IR Spectrum of } 17 & \text { S46 }\end{array}$

$\begin{array}{ll}\text { HR Mass Report of } 18 & \text { S47 }\end{array}$

$\begin{array}{lr}{ }^{1} \mathrm{H} \text { NMR Spectrum of } 18 & \text { S48 }\end{array}$

$\begin{array}{lr}{ }^{13} \text { C NMR Spectrum of } 18 & \text { S49 }\end{array}$

$\begin{array}{lr}\text { IR Spectrum of } 18 & \text { S50 }\end{array}$

X-Ray Structure Determination of $18 \quad$ S51-S58 
Winkler, J. D.; Mikochik, P. J.

Synthesis of Cyclic Hemiketals and Spiroketals from Dioxanorbornanes

Experimental Section

\section{EXPERIMENTAL DETAILS}

\section{General Methods}

Solvents used for extraction and purification were HPLC grade from Fisher. Unless otherwise indicated, all reactions were run under an inert atmosphere of Argon. Anhydrous tetrahydrofuran, ethyl ether and dichloromethane were obtained via passage through an activated alumina column. ${ }^{1}$ Commercial reagents were used as received. Trimethylacetaldehyde was distilled before usage. Deuterated solvents were obtained from Cambridge Isotope Labs. Whatman precoated silica gel plates $(250 \mu \mathrm{m})$ were used for analytical TLC. Spots were visualized using $254 \mathrm{~nm}$ ultraviolet light, with either potassium permanganate or anisaldehyde stains as visualizing agents. Chromatographic purifications were performed on Sorbent Technologies silica gel (particle size 32-63 microns). ${ }^{1} \mathrm{H}$ and ${ }^{13} \mathrm{C}$ NMR spectra were recorded at $500 \mathrm{MHz}$ and $125 \mathrm{MHz}$, respectively, in $\mathrm{CDCl}_{3}$ (unless otherwise indicated) on a Bruker AM-500 or DRX-500 spectrometer. Chemical shifts are reported relative to internal chloroform $\left(\delta 7.26\right.$ for ${ }^{1} \mathrm{H}$, $\delta 77.0$ for ${ }^{13} \mathrm{C}$ ). Infrared spectra were recorded on a $\mathrm{NaCl}$ plate using a Perkin-Elmer 1600 series Fourier transform infrared spectrometer. High resolution mass spectra were obtained by Dr. Rakesh Kohli at the University of Pennsylvania Mass Spectrometry Service Center on an Autospec high resolution double-focusing electrospray ionization/chemical ionization spectrometer with either DEC 11/73 or OPUS software data system. Single-crystal X-ray diffraction structure determination was performed by Dr. Pat Caroll at the University of Pennsylvania. Melting points were obtained on a Thomas Hoover capillary melting point apparatus and are uncorrected.

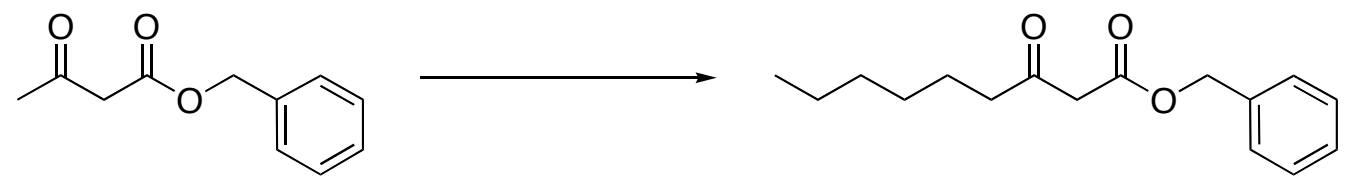

To a solution of diisopropylamine $(1.93 \mathrm{~g}, 19.1 \mathrm{mmol})$ in THF $(23 \mathrm{ml})$ at $0^{0} \mathrm{C}$ was added $\mathrm{n}$-BuLi (2.4 M in hexanes, $7.60 \mathrm{ml}, 18.22 \mathrm{mmol}$ ) and stirred for $30 \mathrm{~min}$. Benzyl acetoacetate $(1.668 \mathrm{~g}, 8.68 \mathrm{mmol})$ was added dropwise and stirred for $1 \mathrm{~h}$ at $0^{0} \mathrm{C}$, during which time the solution turned a deep orange color. At this time, 1-iodopentane $(1.719 \mathrm{~g}$, $8.68 \mathrm{mmol}$ ) in THF (5 ml) was added in one portion, and the solution allowed to gradually warm to rt. After $2 \mathrm{~h}$, the reaction was quenched by the addition of sat'd $\mathrm{NH}_{4} \mathrm{Cl}$, and diluted with $\mathrm{H}_{2} \mathrm{O}$. The aqueous phase was extracted with $\mathrm{Et}_{2} \mathrm{O}(4 \times 30 \mathrm{ml})$,

\footnotetext{
${ }^{1}$ Pangborn, A. B.; Giardello, M. A.; Grubbs, R. H.; Rosen, R. K.; Timmers, F. J. Organometallics 1996, 15,1518 .
} 
then DCM $(2 \times 30 \mathrm{ml})$. The combined organic extracted were washed with brine, dessicated with $\mathrm{Na}_{2} \mathrm{SO}_{4}$, and the solvents removed under reduced pressure. Column chromatography ( $2 \%$ ethyl acetate / hexanes) affected the separation of product (1.0303 $\mathrm{g}, 41 \%$ ) as a pale yellow oil: IR (thin film): 2955, 2930, 2858, 1746, 1715, 1649 and $1151 \mathrm{~cm}^{-1} ;{ }^{1} \mathrm{H}$ NMR $\left(500 \mathrm{MHz}, \mathrm{CDCl}_{3}\right) \delta$ 7.31-7.38 (m, 5H), 5.17 (s, 2H), $3.47(\mathrm{~s}, 2 \mathrm{H})$, $2.49(\mathrm{dd}, 2 \mathrm{H}, \mathrm{J}=7.36,7.36 \mathrm{~Hz}), 1.57(\mathrm{~m}, 2 \mathrm{H}), 1.26-1.31(\mathrm{~m}, 6 \mathrm{H}), 0.88(\mathrm{dd}, 3 \mathrm{H}, \mathrm{J}=6.13$, $6.13 \mathrm{~Hz}) ;{ }^{13} \mathrm{C}$ NMR $\left(133 \mathrm{MHz}, \mathrm{CDCl}_{3}\right) \delta 202.53,166.97,135.32,128.51,128.33,128.26$, $66.95,49.13,42.95,31.42,28.56,23.32,22.35$ and 13.90; HRMS calc'd for $\mathrm{C}_{16} \mathrm{H}_{22} \mathrm{O}_{3}$ $(\mathrm{M}+\mathrm{H})$ 262.1569, found 263.1643.

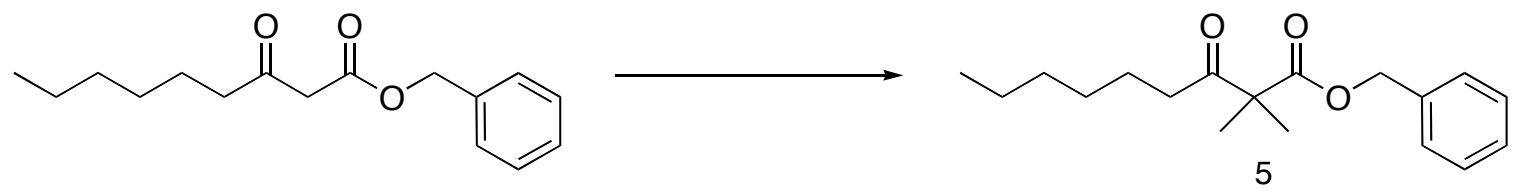

To a solution containing the $\beta$-keto ester $(0.5006 \mathrm{~g}, 1.91 \mathrm{mmol})$ in THF $(20 \mathrm{ml})$ at $0^{0} \mathrm{C}$ was added $95 \% \mathrm{NaH}(0.0580 \mathrm{~g}, 2.29 \mathrm{mmol})$ and let stir for $30 \mathrm{~min}$. The mixture was then warmed to $\mathrm{rt}$, and iodomethane $(0.325 \mathrm{~g}, 2.29 \mathrm{mmol})$ was added in one portion and stirred for $12 \mathrm{~h}$. The reaction was cooled to $0^{0} \mathrm{C}$, and $\mathrm{NaH}(0.0580 \mathrm{~g}, 2.29 \mathrm{mmol})$ was added. After $30 \mathrm{~min}$, the reaction mixture was warmed to $\mathrm{rt}$, and iodomethane $(0.325 \mathrm{~g}$, $2.29 \mathrm{mmol}$ ) was added in one portion, and stirred for $12 \mathrm{~h}$. The mixture was quenched with saturated $\mathrm{NH}_{4} \mathrm{Cl}(25 \mathrm{ml})$ and diluted with $\mathrm{Et}_{2} \mathrm{O}$. The aqueous layer was extracted with $\mathrm{Et}_{2} \mathrm{O}$ ( $3 \times 25 \mathrm{ml}$ ), and the combined organic phases washed with brine, followed by desiccation with $\mathrm{Na}_{2} \mathrm{SO}_{4}$. The organic solvent was removed under reduced pressure. Column chromatography (1.5\% ethyl acetate / hexanes) of the crude residue afforded $0.4671 \mathrm{~g}(84.3 \%)$ of $\mathbf{5}$ as a yellow oil: IR (thin film): 2932, 2857, 1742, 1713, 1456, 1263 and $1145 \mathrm{~cm}^{-1} ;{ }^{1} \mathrm{H}$ NMR $\left(500 \mathrm{MHz}, \mathrm{CDCl}_{3}\right) \delta$ 7.32-7.34 (m, 5H), $5.17(\mathrm{~s}, 2 \mathrm{H}), 2.34$ (dd, $2 \mathrm{H}, \mathrm{J}=7.3,7.3 \mathrm{~Hz}), 1.49(\mathrm{~m}, 2 \mathrm{H}), 1.37(\mathrm{~s}, 6 \mathrm{H}), 0.86(\mathrm{dd}, 3 \mathrm{H}, \mathrm{J}=7.06,7.06 \mathrm{~Hz}) ;{ }^{13} \mathrm{C}$ NMR $\left(133 \mathrm{MHz}, \mathrm{CDCl}_{3}\right) \delta$ 207.77, 173.5, 135.44, 128.53, 128.34, 128.22, 66.89, 55.65, $37.98,31.50,28.70,23.72,22.41,21.88,13.95$; HRMS calcd for $\mathrm{C}_{18} \mathrm{H}_{26} \mathrm{O}_{3} \mathrm{Na}(\mathrm{M}+\mathrm{Na})$ 313.1780, found 313.1765 .

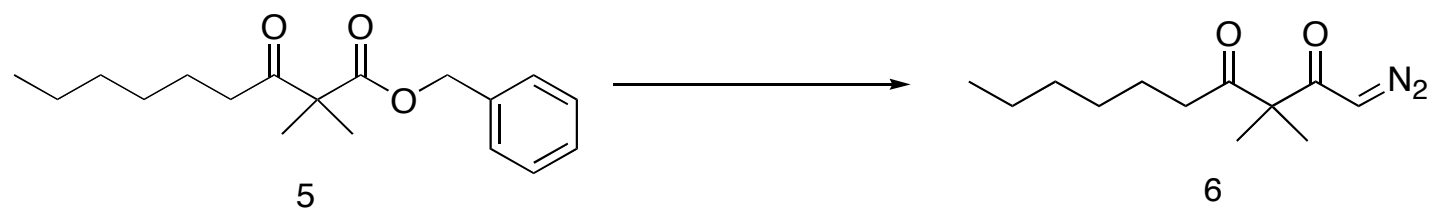

To a solution of $5(0.3423 \mathrm{~g}, 1.18 \mathrm{mmol})$ in $\mathrm{Et}_{2} \mathrm{O}(12 \mathrm{ml})$ was added $\mathrm{Pd}$ on charcoal $(10 \%, 0.60 \mathrm{~g})$. The reaction was stirred under a $\mathrm{H}_{2}$ atmosphere at $0^{0} \mathrm{C}$ for $3 \mathrm{~h}$, at which time the solution was filtered through celite, and used without further purification.

The resultant acid was dissolved in $\mathrm{Et}_{2} \mathrm{O}(10 \mathrm{ml})$, and methyl chloroformate $(0.116 \mathrm{~g}$, $1.23 \mathrm{mmol})$ and $\mathrm{NEt}_{3}(0.124 \mathrm{~g}, 1.23 \mathrm{mmol})$ were added in succession. The mixture was 
allowed to stir for $1.5 \mathrm{~h}$ at $0^{0} \mathrm{C}$ under argon, at which time it was filtered through celite and immediately added to a freshly prepared solution of diazomethane $(0.016 \mathrm{~mol})$ at $0^{0}$ C. The mixture was allowed to react at $\mathrm{rt}$ overnight. Purification by silica gel chromatography (5\% ethyl acetate / hexanes) yielded $0.1811(68.5 \%)$ of $\mathbf{6}$ as a bright yellow oil: IR (thin film): 2929, 2859, 2108, 1716, 1634 and $1349 \mathrm{~cm}^{-1}$; ${ }^{1} \mathrm{H}$ NMR (500 $\left.\mathrm{MHz}, \mathrm{CDCl}_{3}\right) \delta 5.30(\mathrm{~s}, 1 \mathrm{H}), 2.45(\mathrm{dd}, 2 \mathrm{H}, \mathrm{J}=7.41,7.41 \mathrm{~Hz}), 1.53(\mathrm{~m}, 2 \mathrm{H}), 1.32(\mathrm{~s}, 6 \mathrm{H})$, $1.24(\mathrm{~m}, 6 \mathrm{H}), 0.86(\mathrm{dd}, 3 \mathrm{H}, \mathrm{J}=6.67,6.67 \mathrm{~Hz}) ;{ }^{13} \mathrm{C} \mathrm{NMR}\left(133 \mathrm{MHz}, \mathrm{CDCl}_{3}\right) \delta 209.42$, $194.13,60.15,53.56,38.28,31.54,28.73,23.79,22.44,21.89$ and 13.95; HRMS calcd for $\mathrm{C}_{12} \mathrm{H}_{21} \mathrm{~N}_{2} \mathrm{O}_{2}(\mathrm{M}+\mathrm{H})$ 225.1603, found 225.1599.
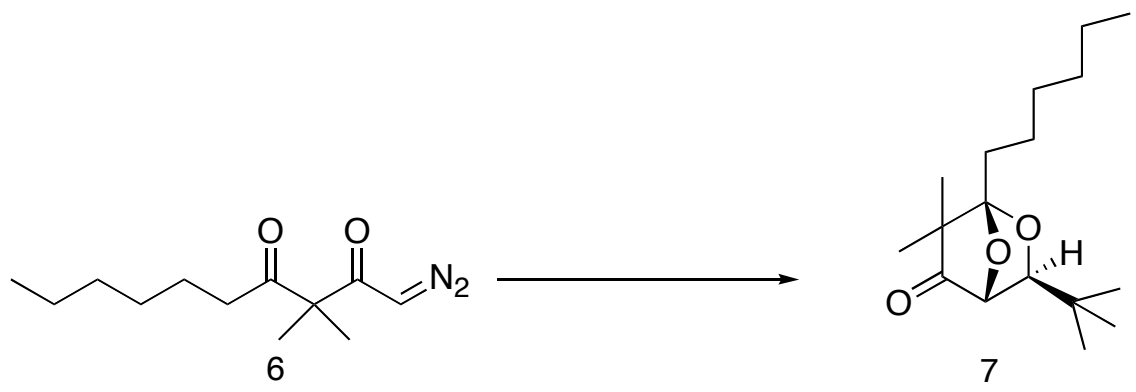

To a degassed solution of $6(0.900 \mathrm{~g}, 4.015 \mathrm{mmol})$ in $\mathrm{CH}_{2} \mathrm{Cl}_{2}(218 \mathrm{ml})$ was added trimethylacetaldehyde $(0.519 \mathrm{~g}, 0.654 \mathrm{ml}, 6.023 \mathrm{mmol})$, followed by $\mathrm{Rh}_{2}(\mathrm{OAc})_{4}(6 \mathrm{~mol}$ $\%$ ). The mixture was stirred at $\mathrm{rt}$ for $1 \mathrm{~h}$ under argon, during which time $\mathrm{N}_{2}$ could be seen evolving from solution. The reaction mixture was concentrated under vacuum, and chromatographed on silica gel (1\% ethyl acetate / hexanes) to afford $1.0125 \mathrm{~g}(89.4 \%)$ of 7 as a pale yellow oil: IR (thin film): 2957, 2933, 1770, 1467 and $989 \mathrm{~cm}^{-1} ;{ }^{1} \mathrm{H}$ NMR $\left(500 \mathrm{MHz}, \mathrm{CDCl}_{3}\right) \delta 4.43(\mathrm{~s}, 1 \mathrm{H}), 3.34(\mathrm{~s}, 1 \mathrm{H}), 1.85(\mathrm{dd}, 2 \mathrm{H}, \mathrm{J}=8.175,8.175 \mathrm{~Hz}), 1.62$ (m, 2H), 1.30-1.39 (m, 6H), $1.08(\mathrm{~s}, 3 \mathrm{H}), 1.03(\mathrm{~s}, 3 \mathrm{H}), 0.92(\mathrm{~s}, 9 \mathrm{H}), 0.90(\mathrm{dd}, 3 \mathrm{H}, \mathrm{J}=$ 6.82, 6.82 Hz); ${ }^{13} \mathrm{C}$ NMR $\left(133 \mathrm{MHz}, \mathrm{CDCl}_{3}\right) \delta$ 2 214.44 114.44, 82.97, 80.69, 52.25, $33.95,31.73,29.65,28.52,25.91,22.61,22.42,20.54,19.74$ and 14.07; HRMS calc'd for $\mathrm{C}_{17} \mathrm{H}_{30} \mathrm{O}_{3}$ 282.2195, found 282.2198.
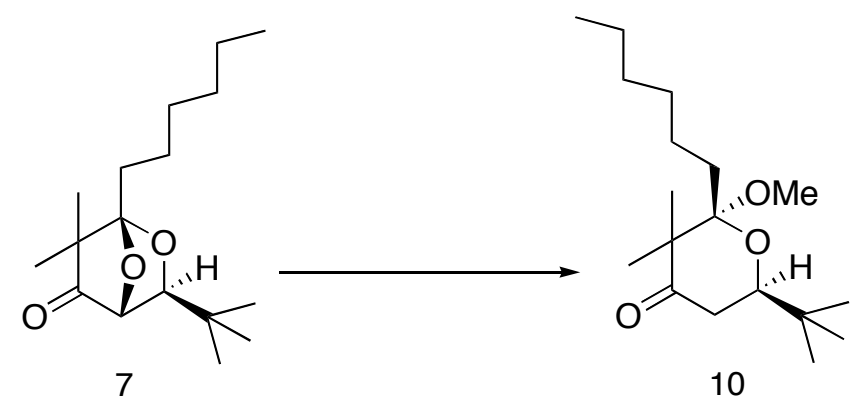

To a flame-dried flask was added Sm metal $(100 \mathrm{mg})$ and THF $(4 \mathrm{ml}) . \mathrm{CH}_{2} \mathrm{I}_{2}(0.028 \mathrm{ml})$ was added over $30 \mathrm{~min}$, at which time the reaction mixture turned a deep blue color. The $\mathrm{SmI}_{2}$ solution was cooled to $-90^{\circ}$ C. $7(0.0278 \mathrm{~g}, 0.095 \mathrm{mmol})$ was dissolved in $2 \mathrm{ml}$ of 2:1 THF:MeOH, and added to the reaction mixture, which was let to stir for $1 \mathrm{~h}$. The 
reaction was quenched at $-90^{\circ} \mathrm{C}$ with saturated $\mathrm{NaHCO}_{3}$, at which time the blue color dissipated. The aqueous layer was extracted with DCM (3 x 25), the combined organic phases desiccated with $\mathrm{Na}_{2} \mathrm{SO}_{4}$ and the solvent removed under reduced pressure. ${ }^{1} \mathrm{H}$ NMR shows a 4:1 mixture of open-chain: hemiketal present (9:8).

The crude residue from above was dissolved in $\mathrm{MeOH}(10 \mathrm{ml})$, followed by the addition of TsOH $(100 \mathrm{mg})$. After $1 \mathrm{~h}$, the mixture was quenched by the addition of saturated $\mathrm{NaHCO}_{3}$. The mixture was extracted with DCM $(4 \times 10 \mathrm{ml})$. The combined organic phases were desiccated with $\mathrm{Na}_{2} \mathrm{SO}_{4}$, and the solvent removed. Silica gel chromatography (2\% ethyl acetate / hexanes) furnished $0.0165 \mathrm{~g}(56 \%)$ of $\mathbf{1 0}$ as a clear oil: IR (thin film): 2956, 1718, 1653, 1466, 1363, 1124, 1069 and $1027 \mathrm{~cm}^{-1} ;{ }^{1} \mathrm{H}$ NMR $\left(500 \mathrm{MHz}, \mathrm{CDCl}_{3}\right) \delta 3.43(\mathrm{dd}, 1 \mathrm{H}, \mathrm{J}=3.49,11.71 \mathrm{~Hz}), 3.15(\mathrm{~s}, 3 \mathrm{H}), 2.51(\mathrm{dd}, 1 \mathrm{H}, \mathrm{J}=$ 11.775, 14.12), $2.18(\mathrm{dd}, 1 \mathrm{H}, \mathrm{J}=3.485,14.13 \mathrm{~Hz}), 1.76(\mathrm{ddd}, 2 \mathrm{H}, \mathrm{J}=3.52,7.66,7.66$ $\mathrm{Hz}), 1.48(\mathrm{~m}, 2 \mathrm{H}), 1.30(\mathrm{~m}, 6 \mathrm{H}), 1.15(\mathrm{~s}, 3 \mathrm{H}), 1.07(\mathrm{~s}, 3 \mathrm{H}), 0.97(\mathrm{~s}, 9 \mathrm{H}), 0.90(\mathrm{dd}, 3 \mathrm{H}, \mathrm{J}=$ $6.53,6.53 \mathrm{~Hz})$;

${ }^{13} \mathrm{CNMR}\left(133 \mathrm{MHz}, \mathrm{CDCl}_{3}\right) \quad \delta$ 212.16, 105.55, 76.02, 53.39, 48.84, 37.69, 34.33, 32.3, 31. 76, 30.38, 25.46, 24.68, 23.47, 22.68, 17.74 and 14.08; HRMS calc'd for $\mathrm{C}_{18} \mathrm{H}_{35} \mathrm{O}_{3}(\mathrm{M}+\mathrm{H})$ 299.2559, found 299.2546.
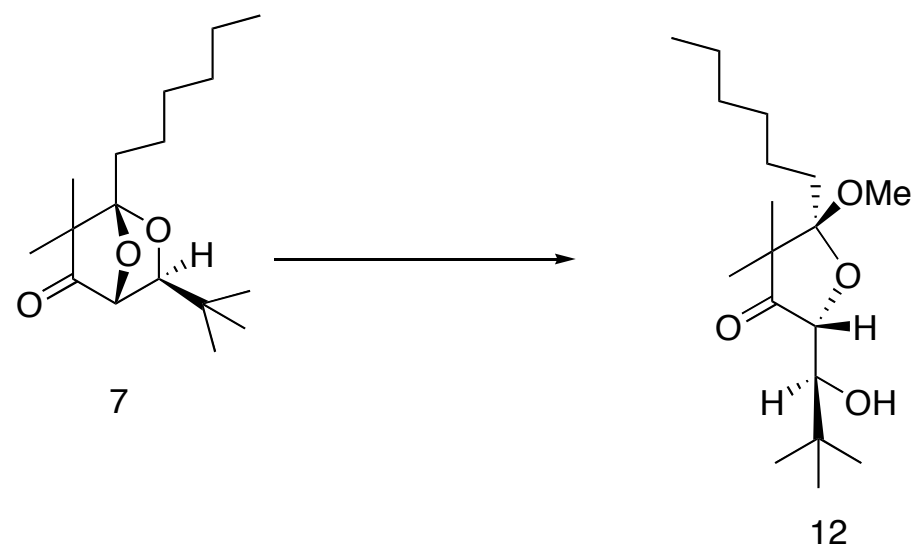

To the 2:2:1 bicycle $7(0.0508 \mathrm{~g}, 0.18 \mathrm{mmol})$ in $\mathrm{MeOH}(0.9 \mathrm{ml})$ was added TsOH $(0.050$ $\mathrm{g}, 1 \mathrm{eq}$.). After $1 \mathrm{~h}$, the reaction was quenched by the addition of saturated $\mathrm{NaHCO}_{3}$. The reaction mixture was extracted with DCM $(4 \times 10 \mathrm{ml})$, the combined organic phases were desiccated with $\mathrm{Na}_{2} \mathrm{SO}_{4}$ and the solvent removed to afford $0.051 \mathrm{~g}(95 \%)$ of the furanone $\mathbf{1 2}$ as the single diastereomer: IR (thin film): 3508, 2956, 2872, 1763, 1466, 1384 and $1068 \mathrm{~cm}^{-1} ;{ }^{1} \mathrm{H}$ NMR $\left(500 \mathrm{MHz}, \mathrm{CDCl}_{3}\right) \delta 3.89(\mathrm{~s}, 1 \mathrm{H}), 3.56(\mathrm{~d}, 1 \mathrm{H}, \mathrm{J}=6.08$ hz), $3.22(\mathrm{~s}, 3 \mathrm{H}), 2.10(\mathrm{br} \mathrm{d}, 1 \mathrm{H}), 1.97(\mathrm{~m}, 2 \mathrm{H}), 1.73(\mathrm{~m}, 2 \mathrm{H}), 1.32(\mathrm{~m}, 6 \mathrm{H}), 1.13(\mathrm{~s}, 3 \mathrm{H})$, 1.04 (s, 3H), 0.98 (s, 9H), 0.90 (dd, 3H, J = 7.94, $7.94 \mathrm{~Hz}) ;{ }^{13} \mathrm{C}$ NMR $\left(133 \mathrm{MHz}, \mathrm{CDCl}_{3}\right)$ $\delta$ 219.62, 109.33, 77.20, 76.58, 50.95, 48.28, 35.30, 31.56, 30.46, 29.68, 26.33, 22.79, 22.57, 20.39, 18.47 and 14.00; HRMS calcd for $\mathrm{C}_{18} \mathrm{H}_{34} \mathrm{O}_{4}(\mathrm{M}+)$ 314.2457, found 314.2447.

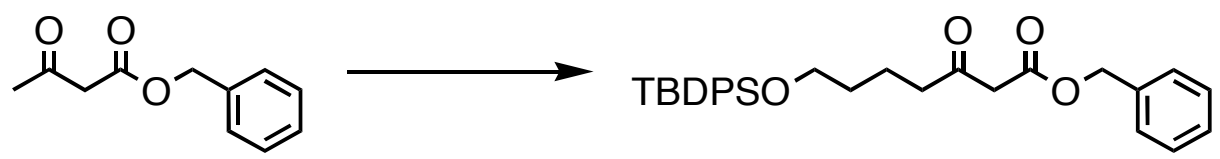


To a solution of diisopropylamine $(0.4297 \mathrm{~g}, 4.23 \mathrm{mmol})$ in THF $(5 \mathrm{ml})$ at $0^{0} \mathrm{C}$ was added $\mathrm{n}-\mathrm{BuLi}(1.96 \mathrm{M}$ in hexanes, $2.07 \mathrm{ml})$ and stirred for $30 \mathrm{~min}$. Benzyl acetoacetate $(0.371 \mathrm{~g}, 1.93 \mathrm{mmol})$ was added dropwise and stirred for $1 \mathrm{~h}$ at $0^{\circ} \mathrm{C}$, during which time the solution turned a deep orange color. At this time, 3 -silyloxy-iodopropane $(0.8181 \mathrm{~g}$, $1.93 \mathrm{mmol})$ in THF ( $1 \mathrm{ml})$ was added in one portion, and the solution allowed to gradually warm to rt. At $2 \mathrm{~h}$, the reaction was quenched by the addition of sat'd $\mathrm{NH}_{4} \mathrm{Cl}$, and diluted with $\mathrm{H}_{2} \mathrm{O}$. The aqueous phase was extracted with $\mathrm{Et}_{2} \mathrm{O}(4 \times 10 \mathrm{ml})$, then DCM $(2 \times 10 \mathrm{ml})$. The combined organic extracted were washed with brine, dessicated with $\mathrm{Na}_{2} \mathrm{SO}_{4}$, and the solvents removed under reduced pressure. Column chromatography ( $1 \%$ ethyl acetate / hexanes) affected the separation of product $(0.4944$ g, 52.5\%) as a pale yellow oil: IR (thin film): 2931, 2857, 1745, 1716, 1649, 1626, 1428, 1110 and $702 \mathrm{~cm}^{-1} ;{ }^{1} \mathrm{H}$ NMR $\left(500 \mathrm{MHz} \mathrm{CDCl}_{3}\right) \delta$ 7.69-7.71 (m, 4H), 7.38-7.45 (m, $11 \mathrm{H}), 5.20$ (s, 2H), $3.69(\mathrm{dd}, 2 \mathrm{H}, \mathrm{J}=6.27,6.27 \mathrm{~Hz}), 3.48(\mathrm{~s}, 2 \mathrm{H}), 2.52(\mathrm{dd}, 2 \mathrm{H}, \mathrm{J}=7.36$, $7.36 \mathrm{~Hz}$ ), 1.72 (dddd, $2 \mathrm{H}, \mathrm{J}=4.74,4.74,4.74,4.74 \mathrm{~Hz}$ ), 1.58 (dddd, 2H, J = 6.22, 6.22, 6.22, 6.22 Hz), $1.10(\mathrm{~s}, 9 \mathrm{H}) ;{ }^{13} \mathrm{C} \mathrm{NMR}\left(133 \mathrm{MHz}, \mathrm{CDCl}_{3}\right) \delta$ 202.27, 166.93, 135.49, $133.87,129.52$, 128.56, 128.53, 128.29, 128.16, 127.58, 66.98, 63.31, 49.07, 42.61, 31.73, 26.83, 19.82 and 19.14; HRMS calc'd for $\mathrm{C}_{30} \mathrm{H}_{36} \mathrm{O}_{4} \mathrm{SiNa}(\mathrm{M}+\mathrm{Na})$ 511.2280, found 511.2291.

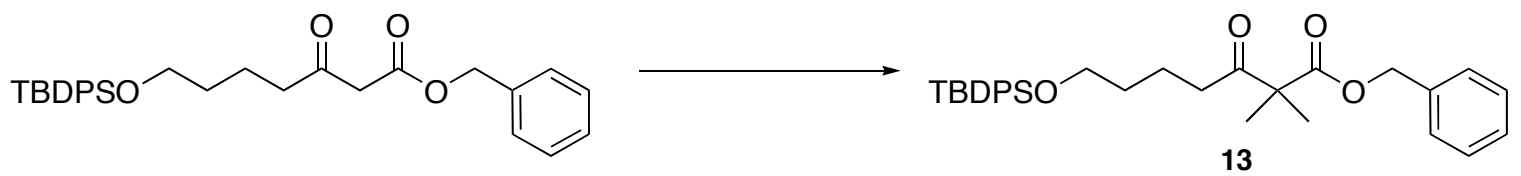

To a solution containing the $\beta$-keto ester $(3.03 \mathrm{~g}, 6.2 \mathrm{mmol})$ in $\mathrm{THF}(65 \mathrm{ml})$ at $0^{\circ} \mathrm{C}$ was added $95 \% \mathrm{NaH}(0.172 \mathrm{~g}, 6.82 \mathrm{mmol})$ and let stir for $30 \mathrm{~min}$. The mixture was warmed to $\mathrm{rt}$ and iodomethane $(1.056 \mathrm{~g}, 7.44 \mathrm{mmol}$ ) was added in one portion and stirred for $12 \mathrm{~h}$. The reaction was cooled to $0^{\circ} \mathrm{C}$, and $\mathrm{NaH}(0.172 \mathrm{~g}, 6.82 \mathrm{mmol})$ was added. After 30 $\mathrm{min}$, the reaction mixture was warmed to $\mathrm{rt}$, and iodomethane (1.056 $\mathrm{g}, 7.44 \mathrm{mmol})$ was added in one portion, and stirred for $12 \mathrm{~h}$. The mixture was quenched with saturated $\mathrm{NH}_{4} \mathrm{Cl}(75 \mathrm{ml})$ and diluted with $\mathrm{Et}_{2} \mathrm{O}$. The aqueous layer was extracted with $\mathrm{Et}_{2} \mathrm{O}(3 \times 75$ $\mathrm{ml}$ ), and the combined organic phases washed with brine, followed by desiccation with $\mathrm{Na}_{2} \mathrm{SO}_{4}$. The organic solvent was removed under reduced pressure. Column chromatography (1\% ethyl acetate / hexanes) of the crude residue afforded $2.5248 \mathrm{~g}$ (78.8 $\%$ ) of 13 as a yellow oil: IR (thin film): 2932, 2858, 1742, 1714, 1262, 1143, 1111 and $702 \mathrm{~cm}^{-1}$; ${ }^{1} \mathrm{H}$ NMR $\left(500 \mathrm{MHz}, \mathrm{CDCl}_{3}\right) \delta 7.66(\mathrm{~m}, 4 \mathrm{H}), 7.29-7.44(\mathrm{~m}, 11 \mathrm{H}), 5.14(\mathrm{~s}, 2 \mathrm{H})$, $3.60(\mathrm{dd}, 2 \mathrm{H}, \mathrm{J}=6.29,6.29 \mathrm{~Hz}), 2.36(\mathrm{dd}, 2 \mathrm{H}, \mathrm{J}=7.17,7.17 \mathrm{~Hz}), 1.61$ (dddd, 2H, J = 7.62, 7.62, 7.62, $7.62 \mathrm{~Hz}), 1.44(\mathrm{~m}, 2 \mathrm{H}), 1.37(\mathrm{~s}, 6 \mathrm{H}), 1.05(\mathrm{~s}, 9 \mathrm{H}) ;{ }^{13} \mathrm{C}$ NMR $(133 \mathrm{MHz}$, $\left.\mathrm{CDCl}_{3}\right) \delta 207.60,173.47,135.54,135.43,133.98,129.53,128.56,128.36,128.23$, 127.59, 66.91, 63.50, 55.63, 37.70, 31.86, 26.85, 21.91, 20.23 and 19.19; HRMS calc'd for $\mathrm{C}_{32} \mathrm{H}_{40} \mathrm{O}_{4} \mathrm{SiNa}(\mathrm{M}+\mathrm{Na}) 539.2593$, found 539.2594. 


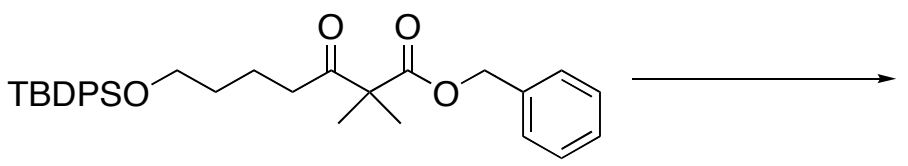

13

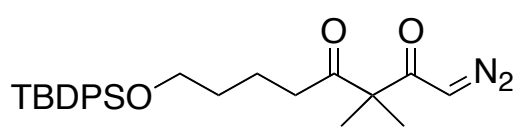

14

To a solution of 13 (2.5248 $\mathrm{g}, 4.89 \mathrm{mmol})$ in $\mathrm{Et}_{2} \mathrm{O}(52 \mathrm{ml})$ was added $\mathrm{Pd}$ on charcoal $(10 \%, 0.262 \mathrm{~g})$. The reaction was stirred under a $\mathrm{H}_{2}$ atmosphere at $0^{0} \mathrm{C}$ for $3 \mathrm{~h}$, at which time the solution was filtered through celite, and used without further purification.

The resultant acid was dissolved in $\mathrm{Et}_{2} \mathrm{O}(17 \mathrm{ml})$, and methyl chloroformate $(0.378 \mathrm{~g}$, $4.89 \mathrm{mmol})$ and $\mathrm{NEt}_{3}(0.682 \mathrm{~g}, 4.89 \mathrm{mmol})$ were added in succession. The mixture was allowed to stir for $1.5 \mathrm{~h}$ at $0^{\circ} \mathrm{C}$ under argon, at which time it was filtered through celite and immediately added to a freshly prepared solution of diazomethane $(0.016 \mathrm{~mol})$ at $0^{0}$ C. The mixture was allowed to warm to rt overnight. Purification by silica gel chromatography (5\% ethyl acetate / hexanes) yielded $1.3136 \mathrm{~g}(59.7 \%)$ of $\mathbf{1 4}$ as a bright yellow oil: IR (thin film): 2932, 2858, 2109, 1712, 1634, 1471, 1349, 1111 and $703 \mathrm{~cm}^{-1}$; ${ }^{1} \mathrm{H}$ NMR $\left(500 \mathrm{MHz}, \mathrm{CDCl}_{3}\right) \delta$ 7.65-7.67 (m, $\left.4 \mathrm{H}\right), 7.37-7.42(\mathrm{~m}, 6 \mathrm{H}), 5.27(\mathrm{~s}, 1 \mathrm{H}), 3.65$ $(\mathrm{dd}, 2 \mathrm{H}, \mathrm{J}=6.24,6.24 \mathrm{~Hz}), 2.48(\mathrm{dd}, 2 \mathrm{H}, \mathrm{J}=7.2,7.2 \mathrm{~Hz}), 1.65$ (dddd, $2 \mathrm{H}, \mathrm{J}=7.30,7.30$, 7.30, 7.30 Hz), 1.54 (dddd, 2H, J = 6.16, 6.16, 6.16, $6.16 \mathrm{~Hz}), 1.33$ (s, 6H), 1.05 (s, 9H); ${ }^{13} \mathrm{C}$ NMR $\left(133 \mathrm{MHz}, \mathrm{CDCl}_{3}\right) \delta 209.19,194.05,135.53,133.93,129.52,127.59,63.49$, $60.08,53.56,38.02,31.83,26.82,21.92,20.31$ and 19.17; HRMS calc'd for $\mathrm{C}_{26} \mathrm{H}_{34} \mathrm{~N}_{2} \mathrm{O}_{3} \mathrm{SiNa}(\mathrm{M}+\mathrm{Na})$ 473.2237, found 473.2232.

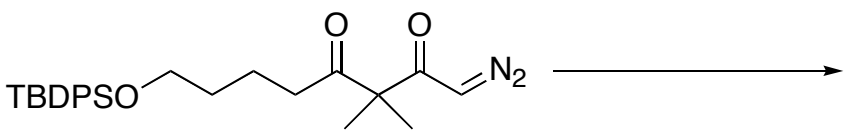

14

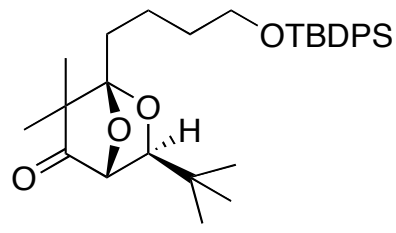

15

To a degassed solution of $14(1.3136 \mathrm{~g}, 2.92 \mathrm{mmol})$ in $\mathrm{CH}_{2} \mathrm{Cl}_{2}(159 \mathrm{ml})$ was added trimethylacetaldehyde $(0.377 \mathrm{~g}, 4.38 \mathrm{mmol})$, followed by $\mathrm{Rh}_{2}(\mathrm{OAc})_{4}(5 \mathrm{~mol} \%)$. The mixture was stirred at $\mathrm{rt}$ for $1 \mathrm{~h}$ under argon, during which time $\mathrm{N}_{2}$ could be seen evolving from solution. The reaction mixture was concentrated under vacuum, and chromatographed on silica gel (1\% ethyl acetate / hexanes) to afford $1.1817 \mathrm{~g}(79.9 \%)$ of 15 as a pale yellow oil: IR (thin film): 2959, 2859, 1769, 1470, 1428, 1112, 990 and 702 $\mathrm{cm}^{-1}$; ${ }^{1} \mathrm{H} \mathrm{NMR}\left(500 \mathrm{MHz}, \mathrm{CDCl}_{3}\right) \delta$ 7.68-7.70 (m, 4H), 7.37-7.43, (m, 6H), $4.45(\mathrm{~s}, 1 \mathrm{H})$, $3.72(\mathrm{dd}, 2 \mathrm{H}, \mathrm{J}=6.19,6.19 \mathrm{~Hz}), 3.36(\mathrm{~s}, 1 \mathrm{H}), 1.66-1.89(\mathrm{~m}, 6 \mathrm{H}), 1.09(\mathrm{~s}, 3 \mathrm{H}), 1.06(\mathrm{~s}$, 9H), 1.04 (s, 3H), 0.93 (s, 9H); ${ }^{13} \mathrm{C}$ NMR $\left(133 \mathrm{MHz}, \mathrm{CDCl}_{3}\right) \delta 214.39,135.57,134.01$, 129.51, 127.60, 114.36, 82.98, 80.70, 63.67, 52.24, 33.96, 32.76, 28.31, 26.84, 25.93, 20.53, 19.70, 19.20 and 19.09; HRMS calcd for $\mathrm{C}_{31} \mathrm{H}_{44} \mathrm{O}_{4} \mathrm{SiNa}(\mathrm{M}+\mathrm{Na}) 531.2906$, found 531.2899 . 

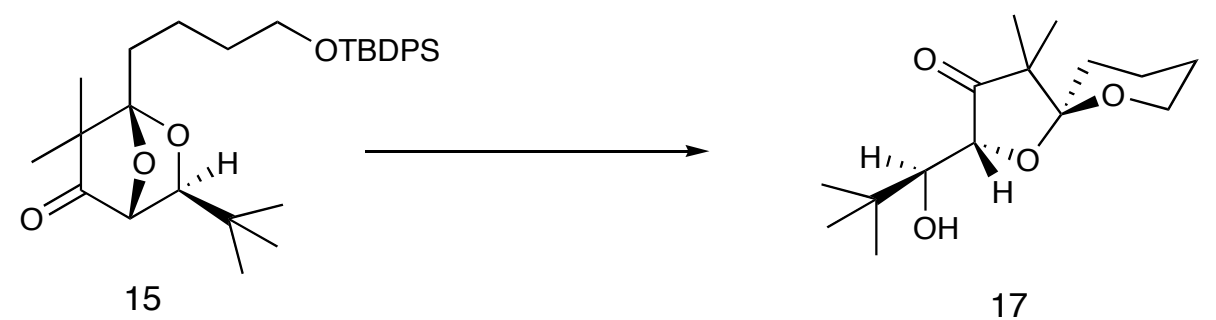

17

The bicycle 15 (0.0563 g, $0.111 \mathrm{mmol})$ was dissolved in $3 \% \mathrm{v} / \mathrm{v} \mathrm{HCl} / \mathrm{MeOH}(5 \mathrm{ml})$ and stirred at rt until all the starting material had disappeared by TLC. The reaction was quenched by the addition of sat'd $\mathrm{NaHCO}_{3}(10 \mathrm{ml})$, and diluted with DCM $(15 \mathrm{ml})$. The aqueous layer was extracted with DCM $(4 \times 10 \mathrm{ml})$, the combined organic phases washed with brine then dried over $\mathrm{Na}_{2} \mathrm{SO}_{4}$. Column chromatography (4\% ethyl acetate / hexanes) furnished $0.0272 \mathrm{~g}(91 \%)$ of $\mathbf{1 7}$ as a white solid $\left(\mathrm{mp}=63.0-64.5^{0} \mathrm{C}\right)$ : IR (thin film): 3494, 2943, 2869, 1760, 1471, 1368, 1211, 1077 and $1043 \mathrm{~cm}^{-1} ;{ }^{1} \mathrm{H}$ NMR $(500 \mathrm{MHz}$, $\left.\mathrm{CDCl}_{3}\right) \delta 3.97(\mathrm{~d}, 1 \mathrm{H}, \mathrm{J}=0.775 \mathrm{~Hz}), 3.77(\mathrm{td}, 1 \mathrm{H}, \mathrm{J}=3.4,11.05,11.05 \mathrm{~Hz}), 3.65-3.68$ $(\mathrm{m}, 1 \mathrm{H}), 3.59(\mathrm{~d}, 1 \mathrm{H}, \mathrm{J}=4.295 \mathrm{~Hz}), 2.08(\mathrm{~d}, 1 \mathrm{H}, \mathrm{J}=8.31 \mathrm{~Hz}), 1.90$, (tt, $1 \mathrm{H}, \mathrm{J}=3.39$, 3.39, 13.64, 13.64 Hz), 1.73-1.81 (m, 2H), 1.53-1.64 (m, 3H), 1.05 (s, 3H), $1.02(\mathrm{~s}, 3 \mathrm{H})$, $0.98(\mathrm{~s}, 9 \mathrm{H}) ;{ }^{13} \mathrm{C}$ NMR $\left(133 \mathrm{MHz}, \mathrm{CDCl}_{3}\right) \delta 219.66,106.25,77.18,76.53,61.78,50.59$, $35.37,27.52,26.40,24.88,19.62,18.81$ and 17.06; HRMS calc'd for $\mathrm{C}_{15} \mathrm{H}_{26} \mathrm{O}_{4} \mathrm{Na}$ $(\mathrm{M}+\mathrm{Na})$ 293.1729, found 293.1714.

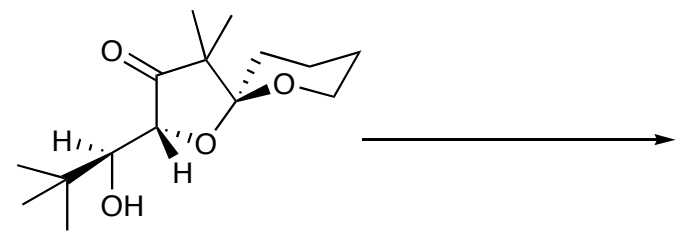

17

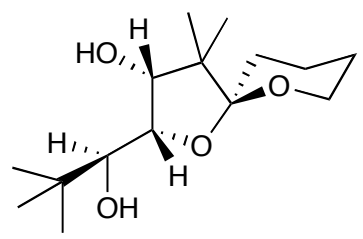

18

To a solution of $17(0.0192 \mathrm{~g}, 0.071 \mathrm{mmol})$ in absolute $\mathrm{EtOH}(0.077 \mathrm{M})$ at $0^{0} \mathrm{C}$ was added $\mathrm{NaBH}_{4}(0.0093 \mathrm{~g}, 0.245 \mathrm{mmol})$. The reaction mixture was allowed to stir for $3 \mathrm{~h}$, at which time the ethanol was evacuated and the residue partitioned between DCM and $\mathrm{H}_{2} \mathrm{O}$. The biphasic mixture was extracted with DCM $(4 \times 10 \mathrm{ml})$, the combined organic extracts were dried over $\mathrm{Na}_{2} \mathrm{SO}_{4}$, and the solvent evacuated. Column chromatography (5\% ethyl acetate / hexanes), followed by slow evaporation from DCM/Hexane afforded $18(0.0170 \mathrm{~g}, 87.9 \%)$ as clear needles $\left(\mathrm{mp}=115^{\circ} \mathrm{C}\right)$ suitable for X-ray diffraction: IR (thin film): 3289, 2958, 2931, 2868, 1469, 1362, 1072, 1059 and $981 \mathrm{~cm}^{-1} ;{ }^{1} \mathrm{H}$ NMR (500 $\left.\mathrm{MHz} \mathrm{CDCl}_{3}\right) \delta 4.17(\mathrm{~d}, 1 \mathrm{H}, \mathrm{J}=7.53 \mathrm{~Hz}), 4.12(\mathrm{~d}, 1 \mathrm{H}, \mathrm{J}=7.55 \mathrm{~Hz}), 3.67(\mathrm{td}, 1 \mathrm{H}, \mathrm{J}=$ 2.77, 11.06, $11.06 \mathrm{~Hz}), 3.59-3.63(\mathrm{~m}, 1 \mathrm{H}), 3.51$ (s, 1H), 2.94 (bs. 1H), 2.34 (bs, 1H) $1.75(\mathrm{tt}, 1 \mathrm{H}, \mathrm{J}=4.08,4.08,12.88,12.88 \mathrm{~Hz}), 1.66-1.69(\mathrm{~m}, 1 \mathrm{H}), 1.45-1.62(\mathrm{~m}, 4 \mathrm{H})$, 1.06 (s, 3H), 1.02 (s, 9H). $0.84(\mathrm{~s}, 3 \mathrm{H}) ;{ }^{13} \mathrm{C} \mathrm{NMR}\left(133 \mathrm{MHz}, \mathrm{CDCl}_{3}\right) \delta 106.62,82.31$, 76.34, 73.85, 61.36, 47.61, 35.18, 27.88, 26.69, 25.22, 21.48, 19.64 and 17.83; HRMS calc'd for $\mathrm{C}_{15} \mathrm{H}_{29} \mathrm{O}_{4}(\mathrm{M}+\mathrm{H})$ 273.2065, found 273.2072. 


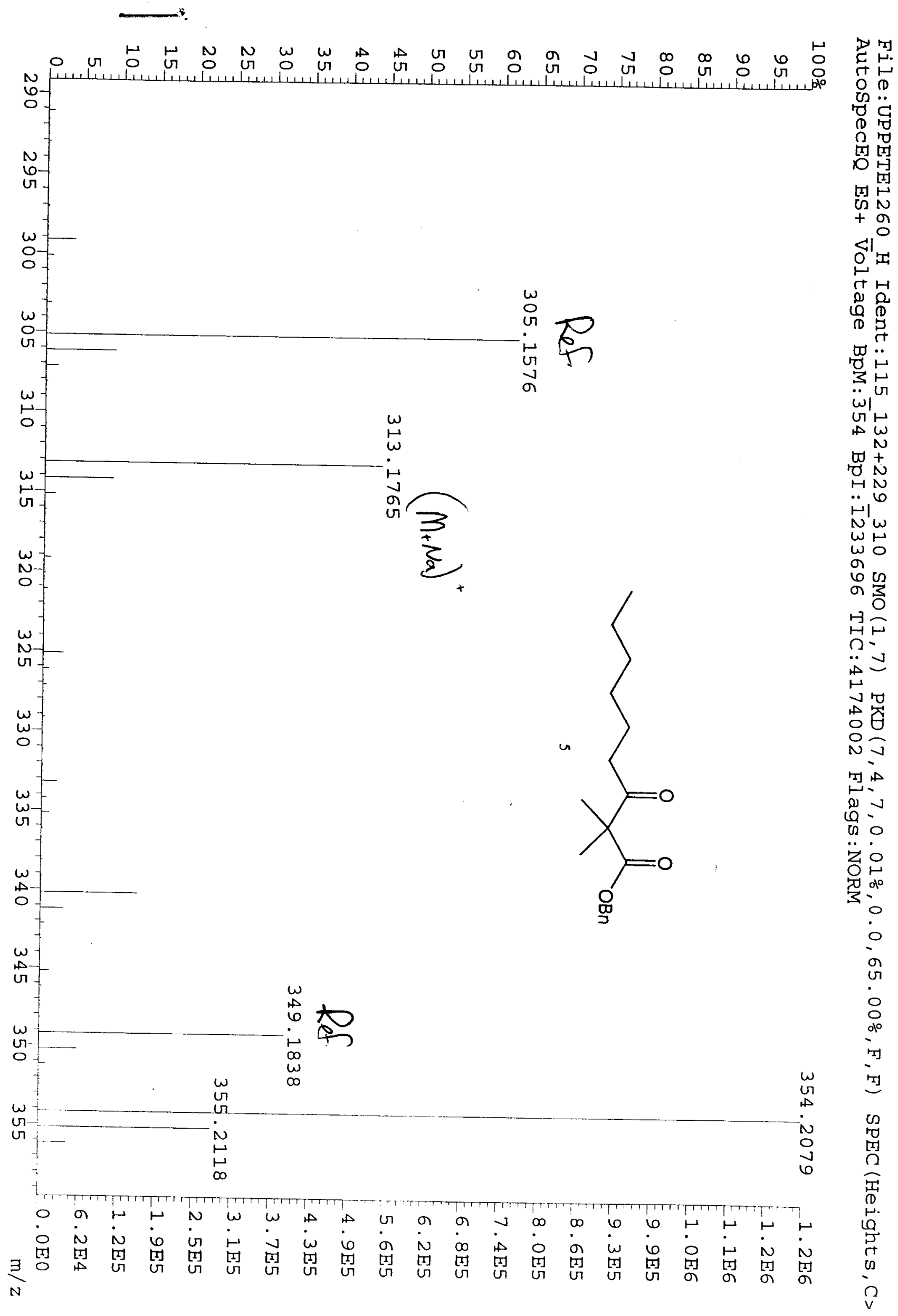



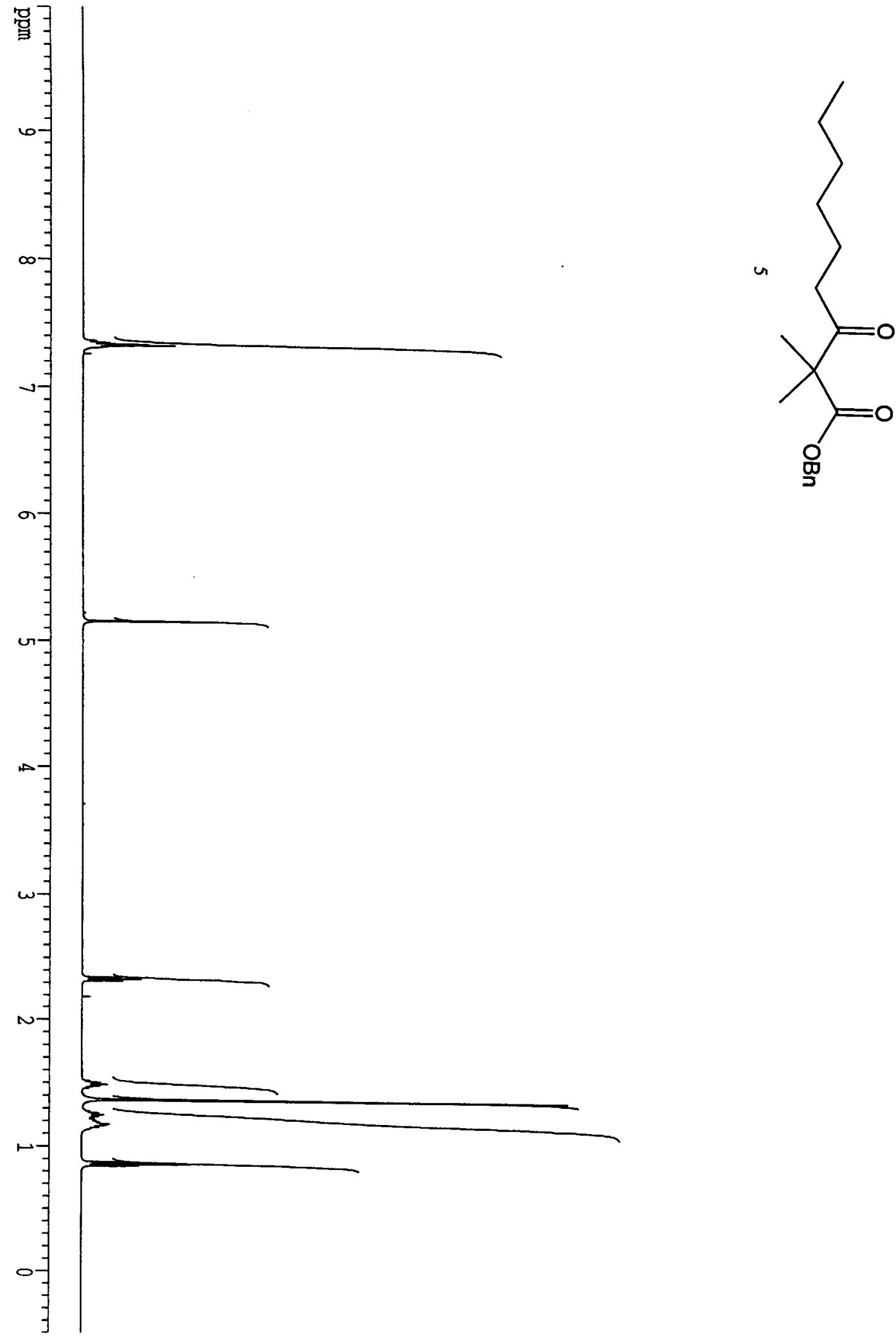


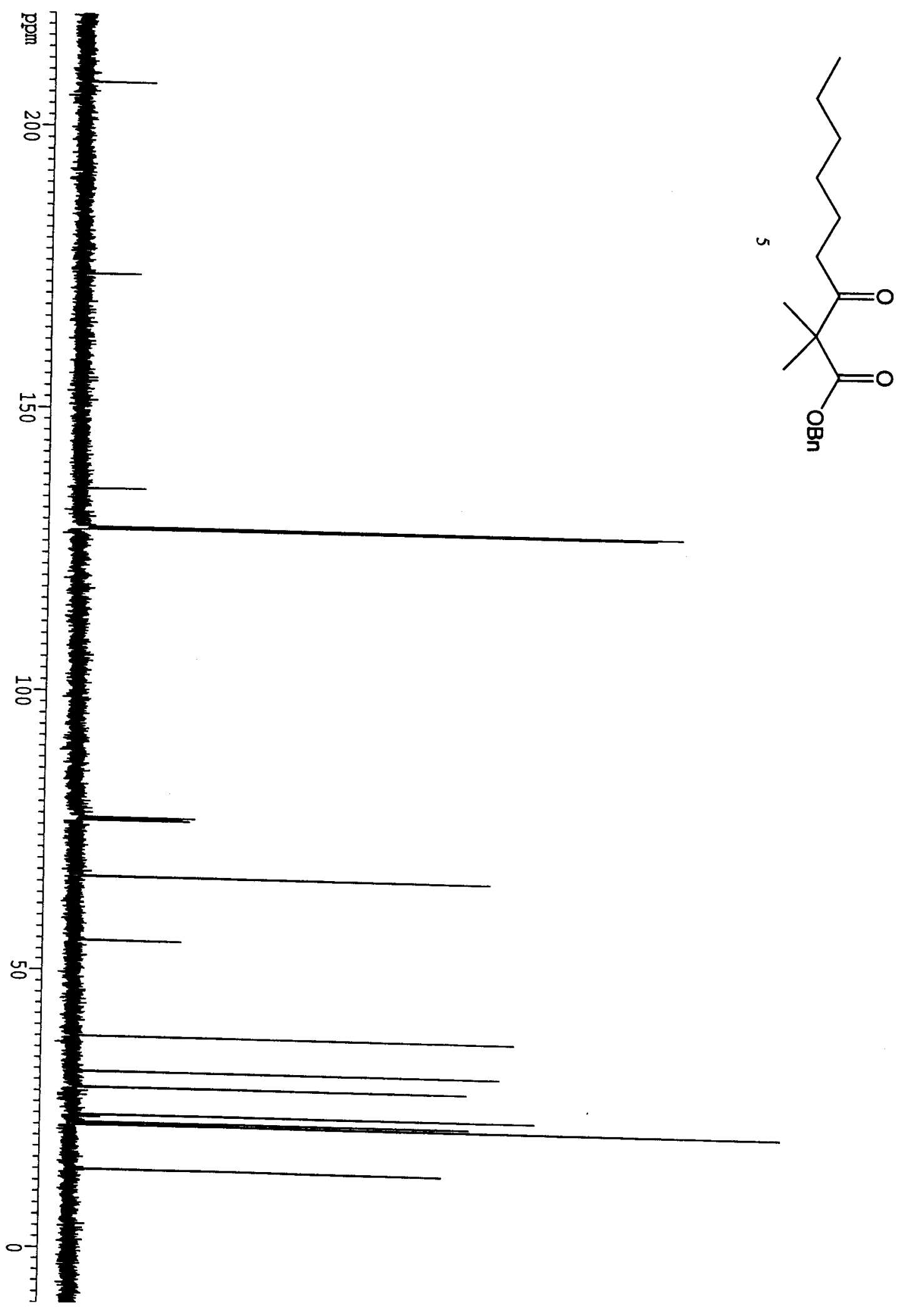

S-13 


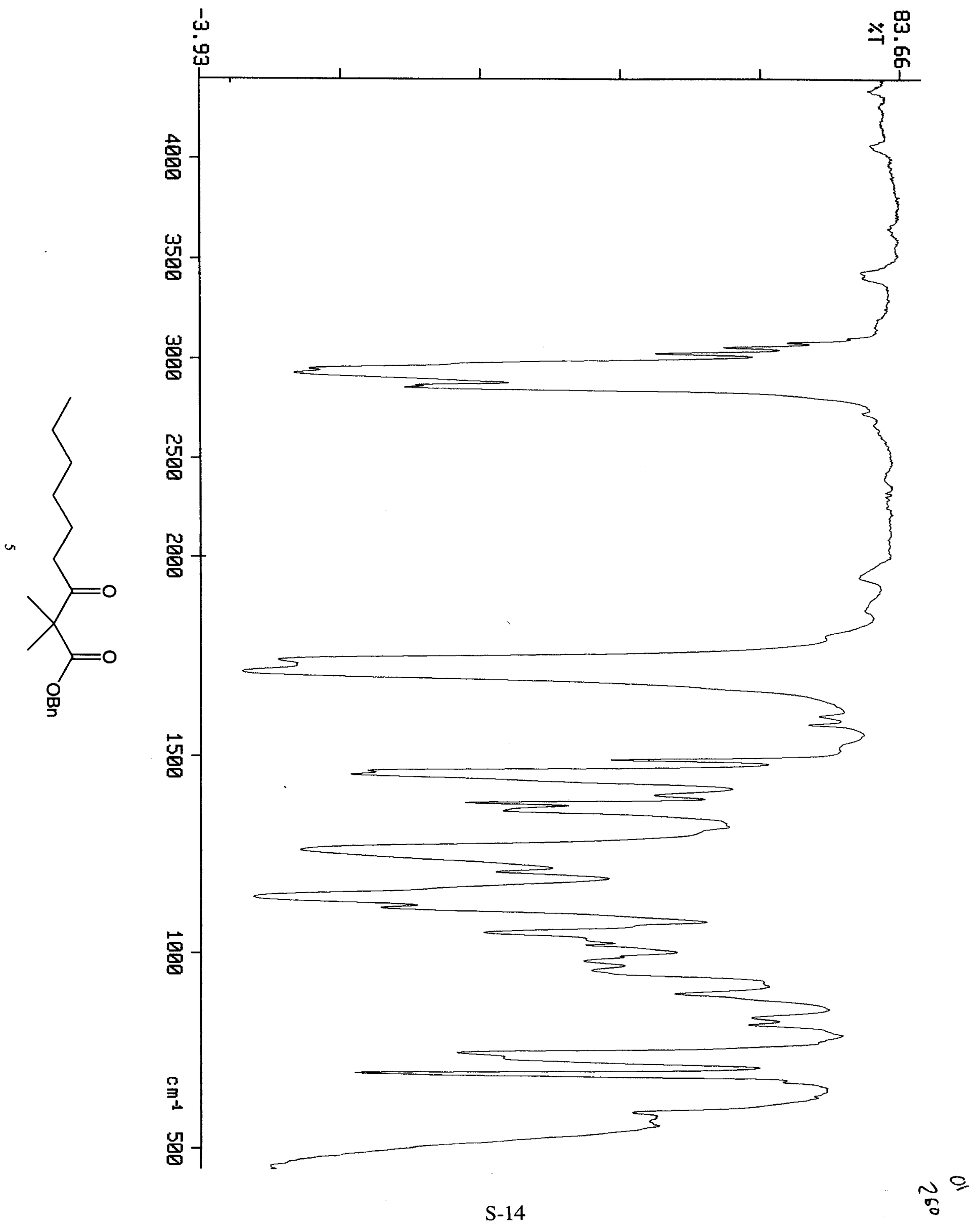




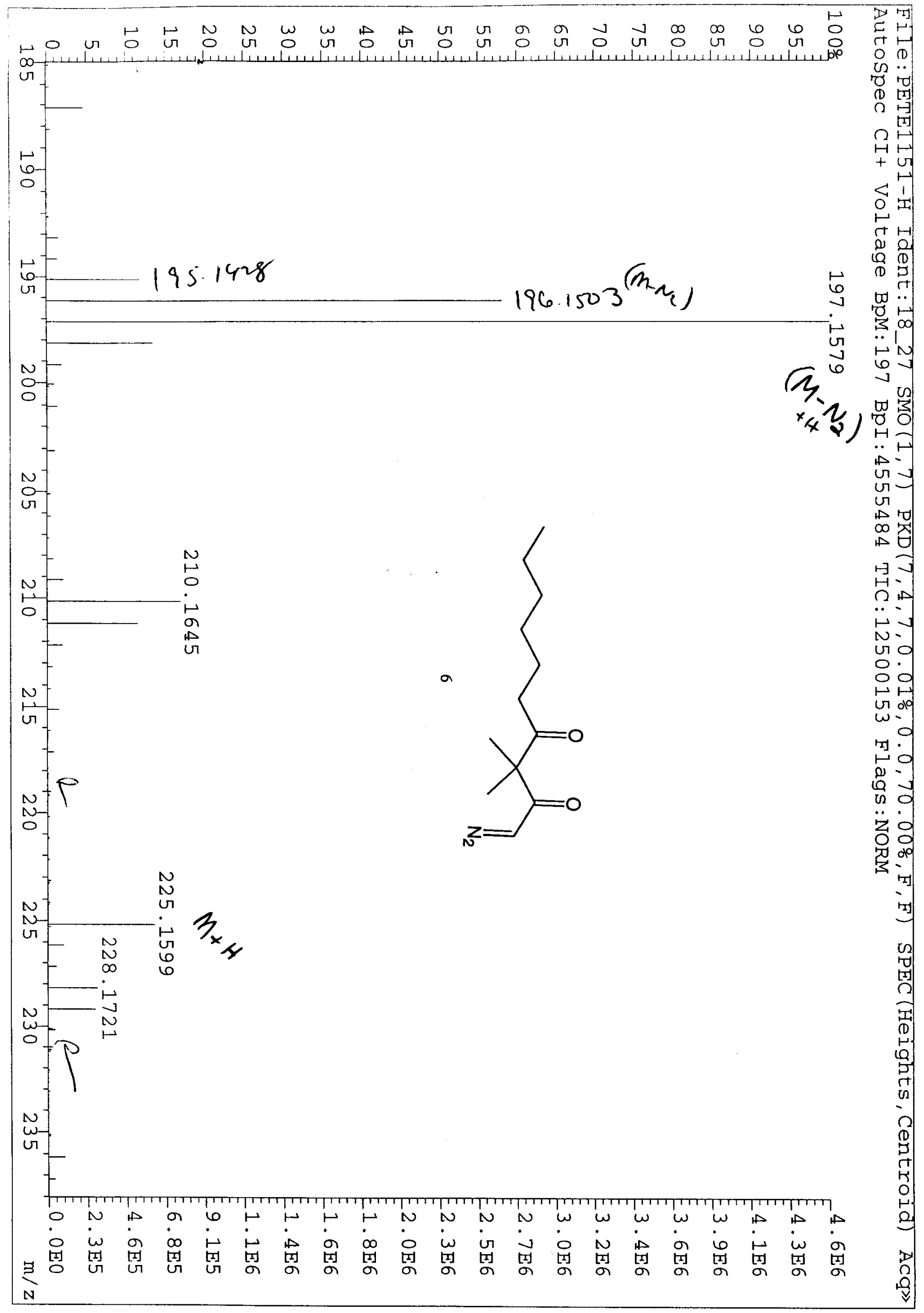




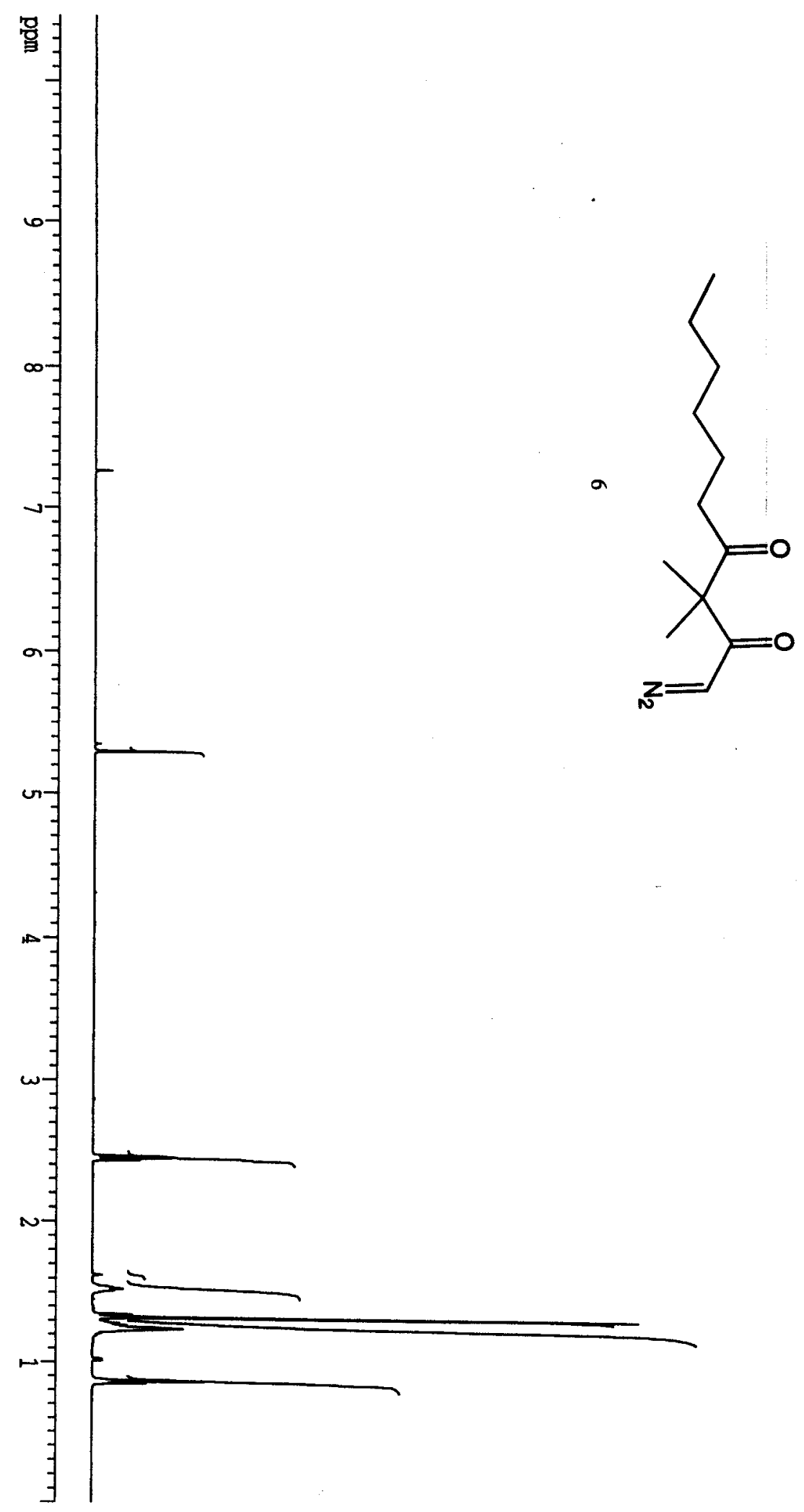




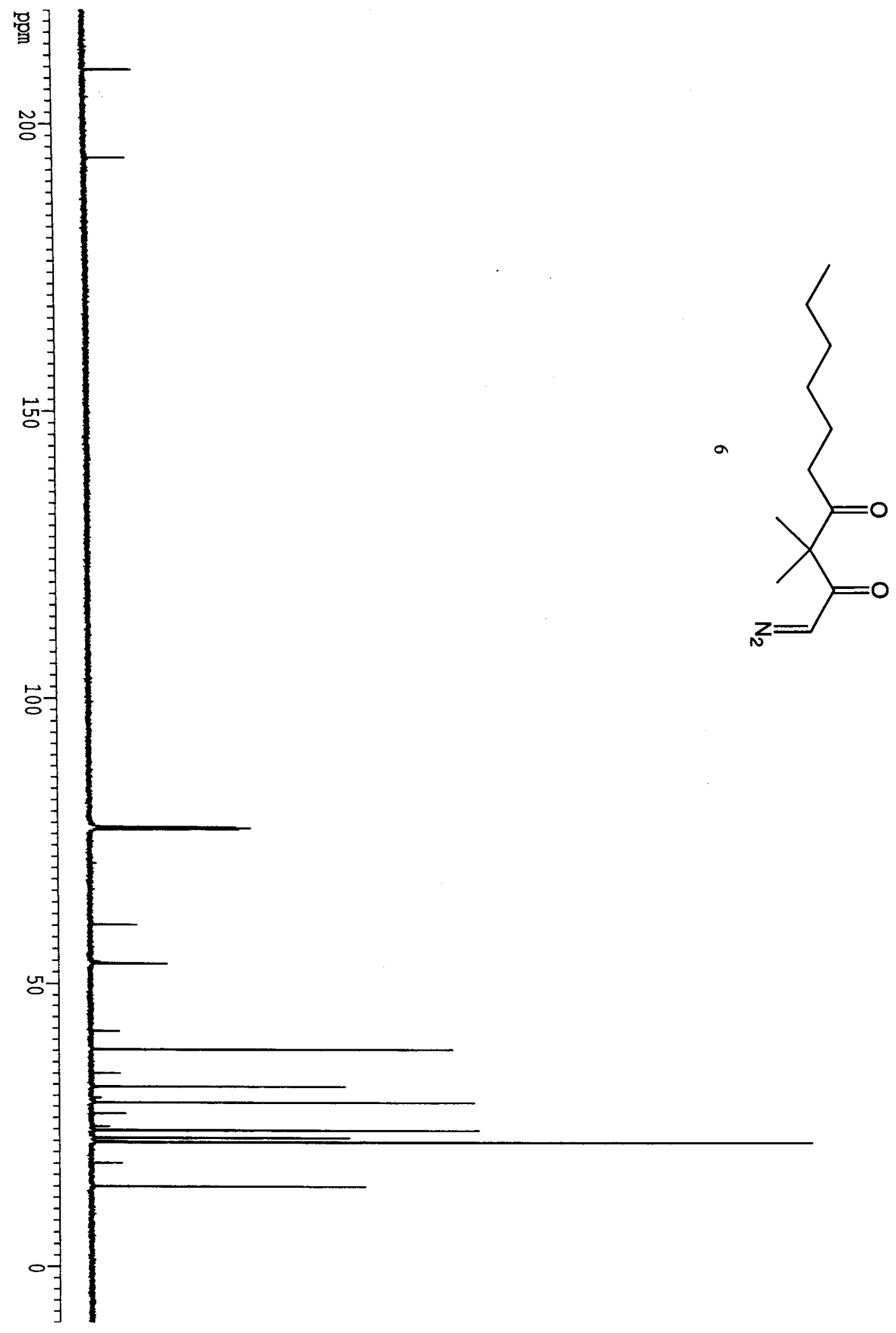




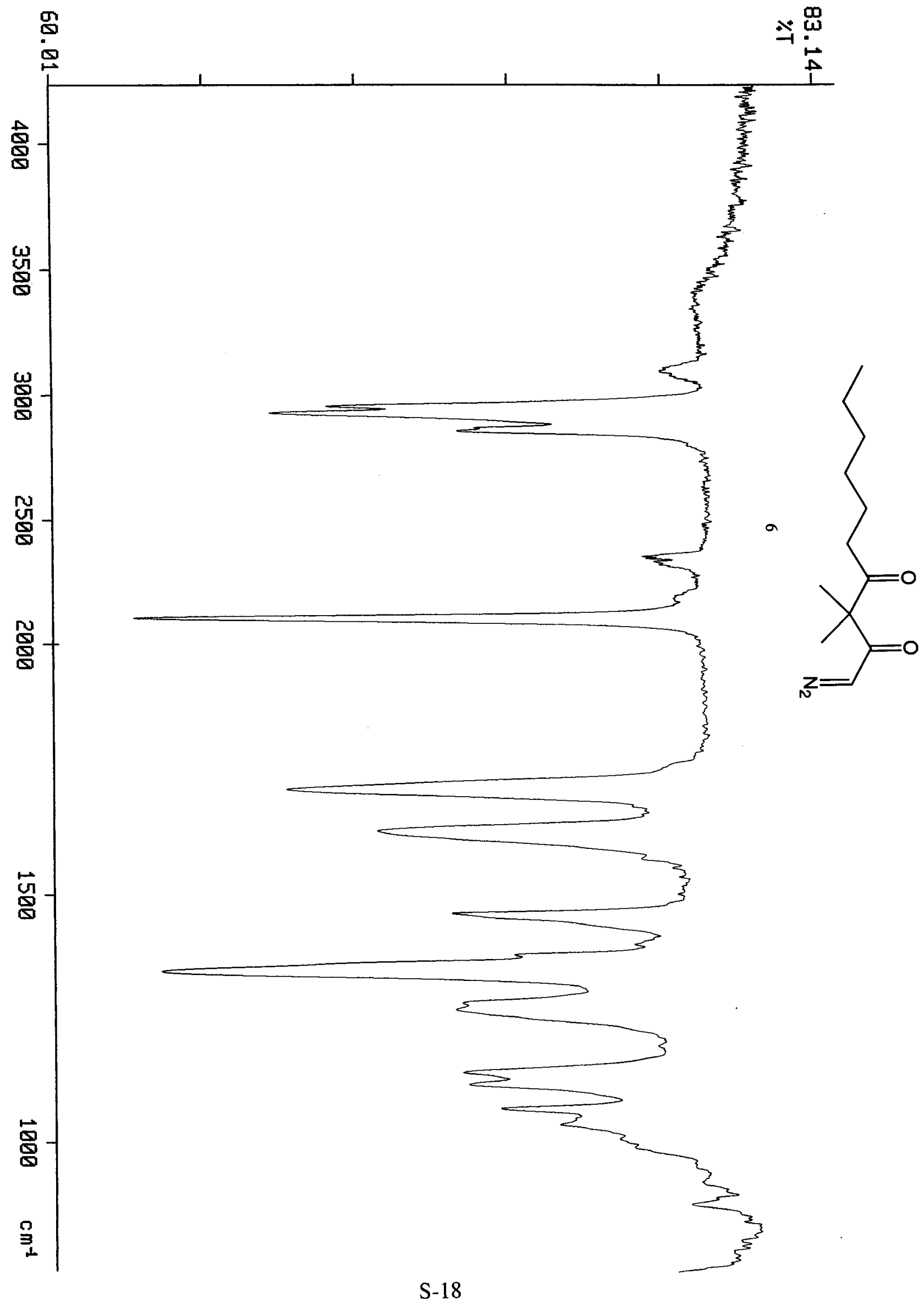




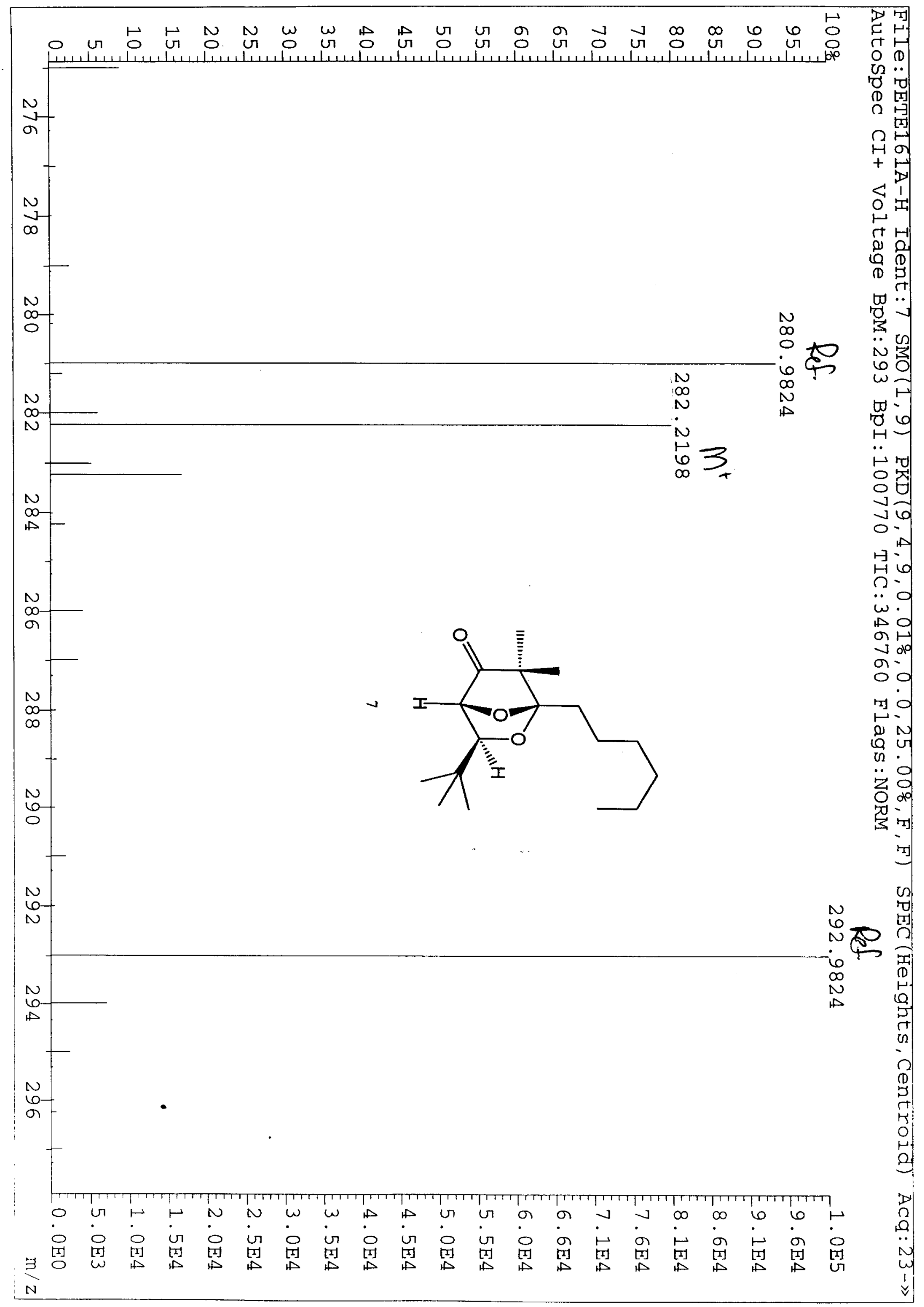




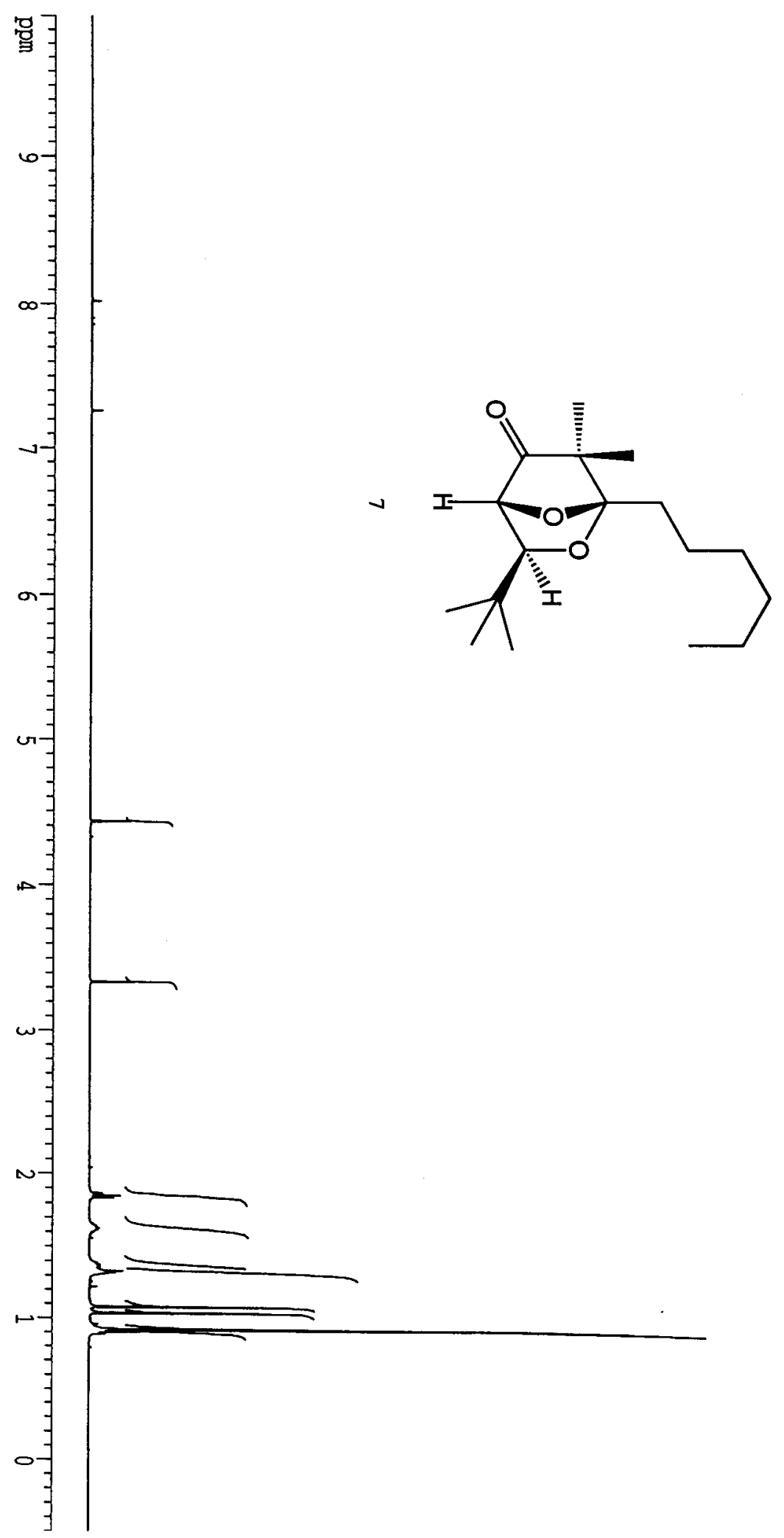




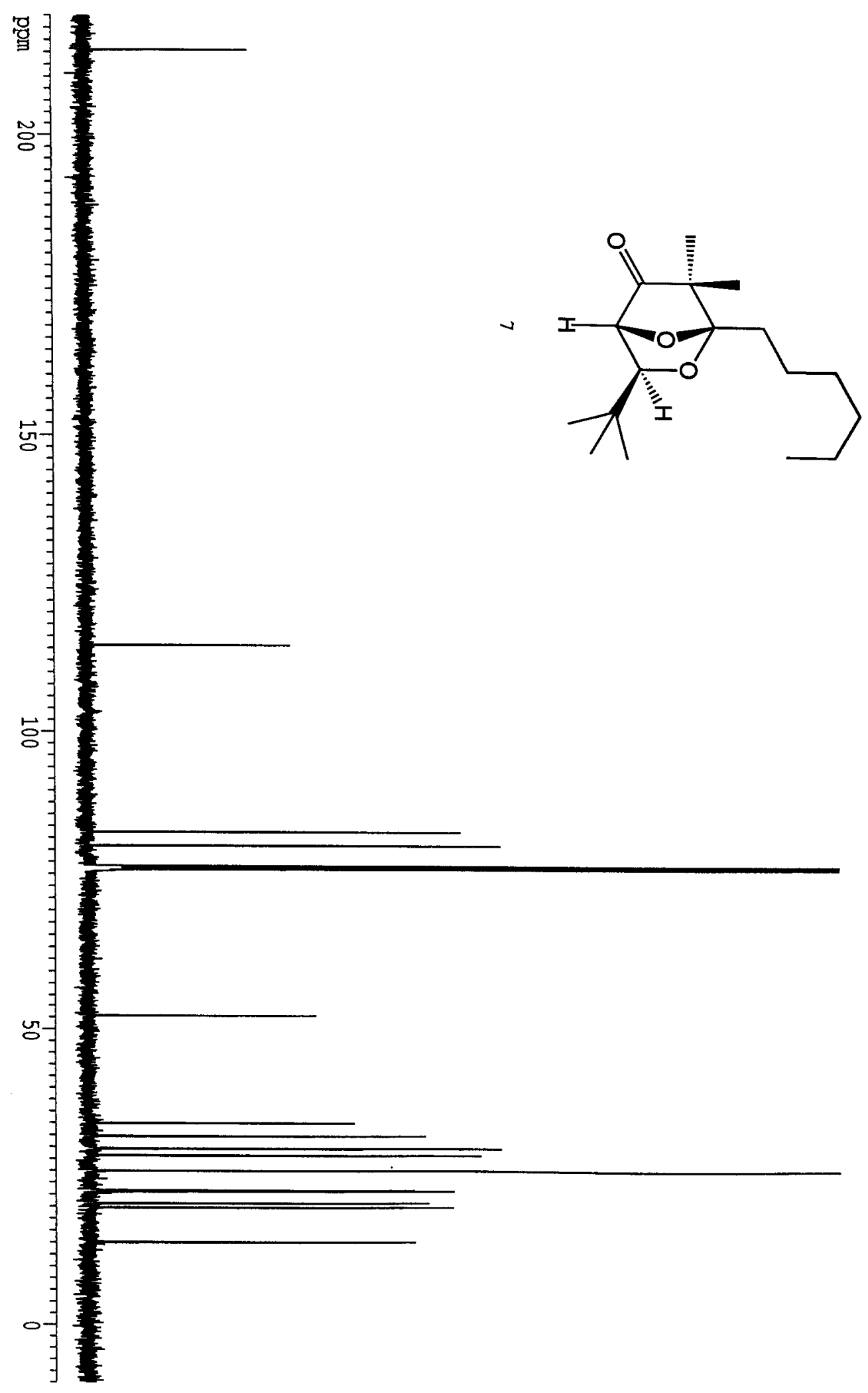


SCAN BACKG 4

4 scans, $4.0 \mathrm{~cm}-1$, single

SCAN X 4

4 scans, $4.0 \mathrm{~cm}-1$

PLOT PEAKS ABSC MANUAL

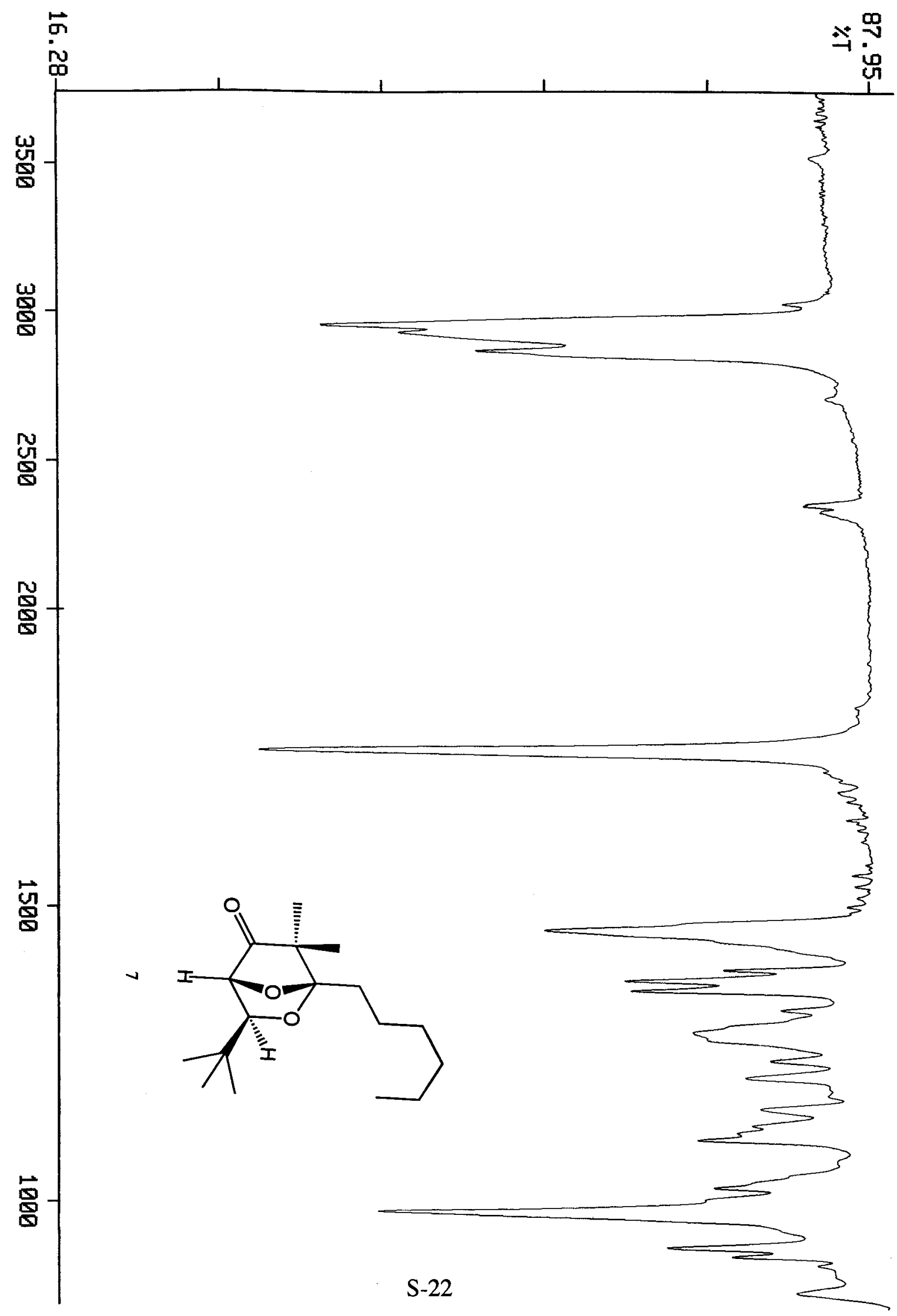




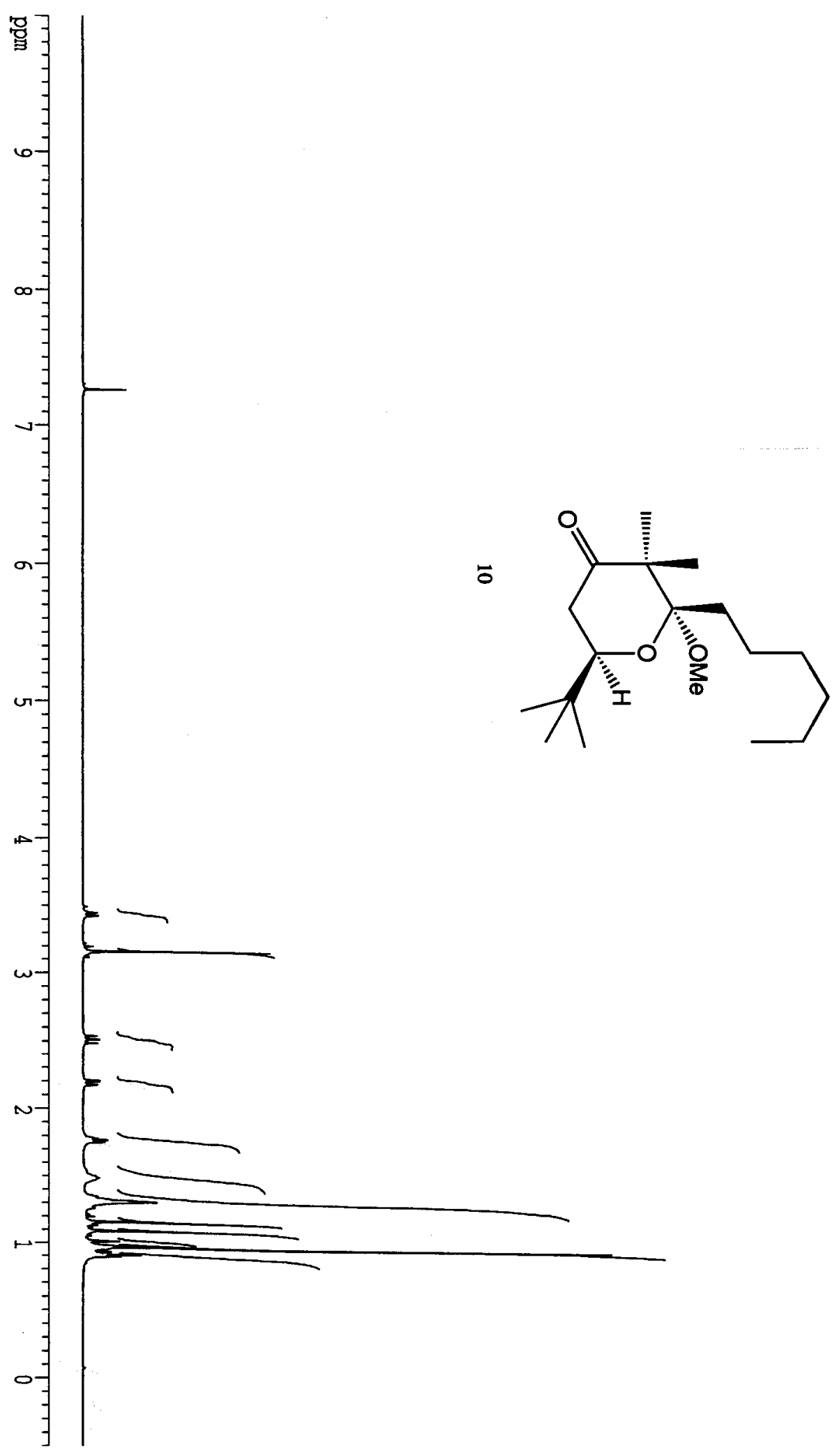




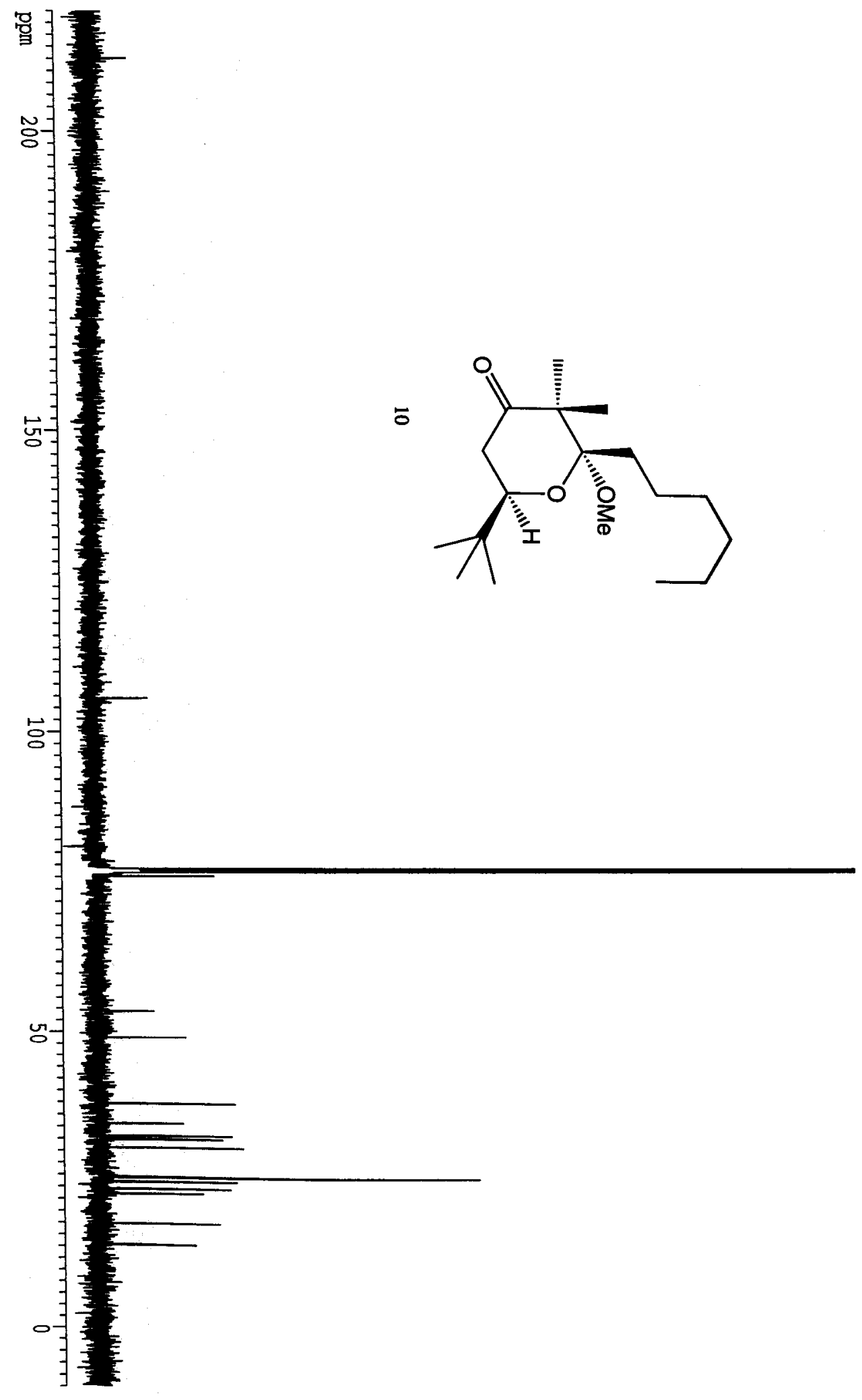


SCAN SCAN 4

4 scans, $4.0 \mathrm{~cm}-1$, single

SCAN SCAN 4

4 scans, $4.0 \mathrm{~cm}-1$

FLAT SCAN $0.0362 \quad 0.0$

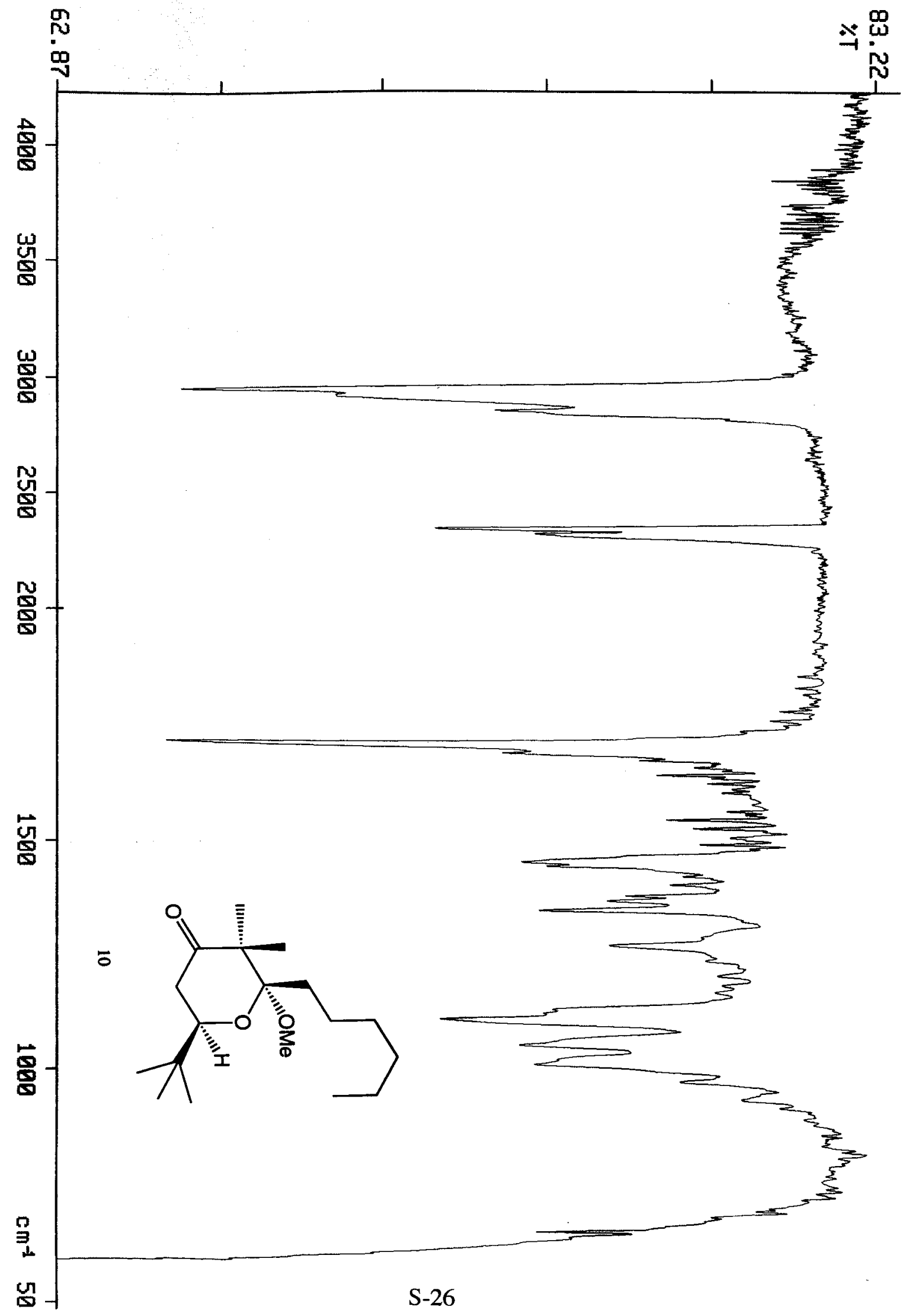




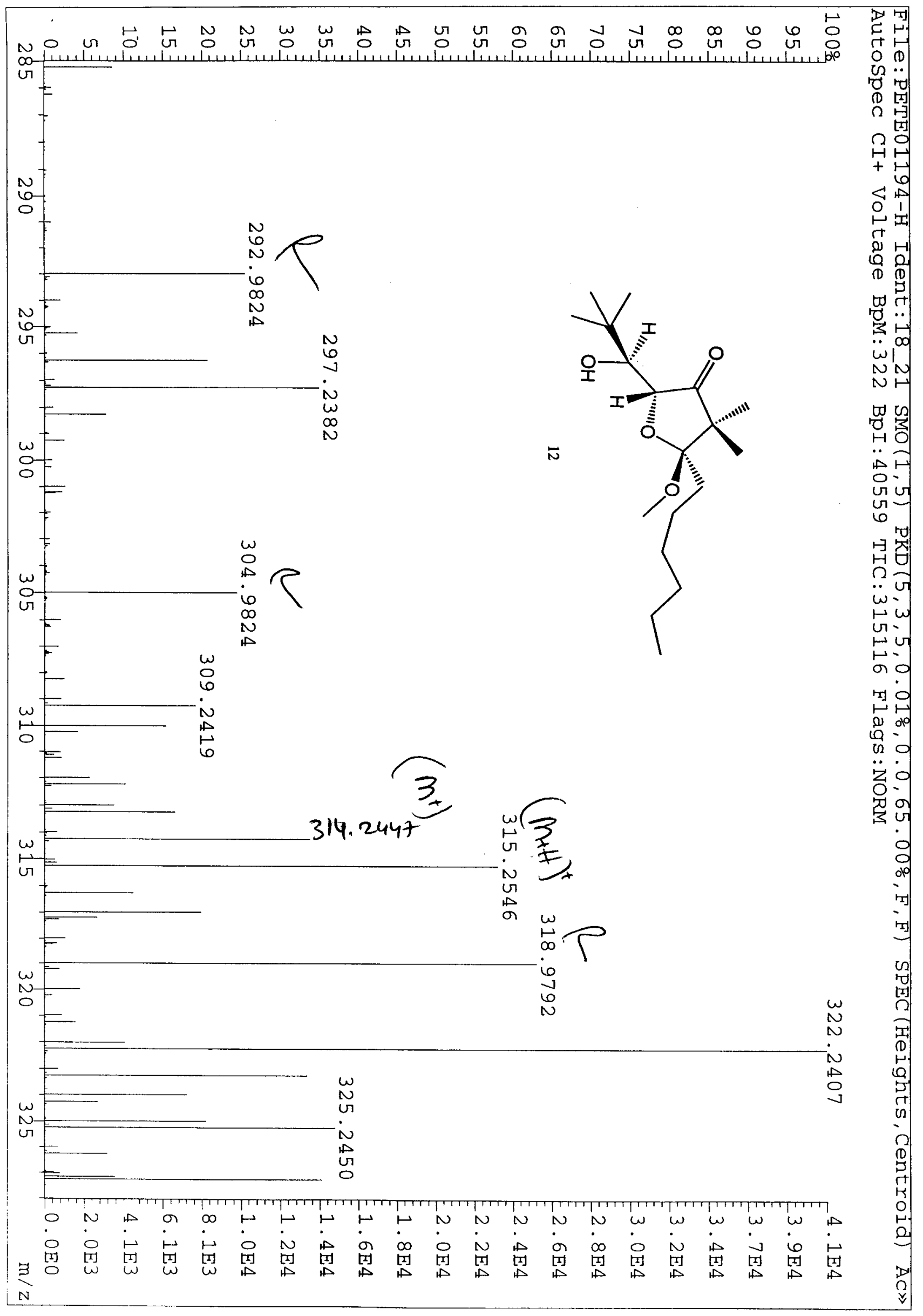




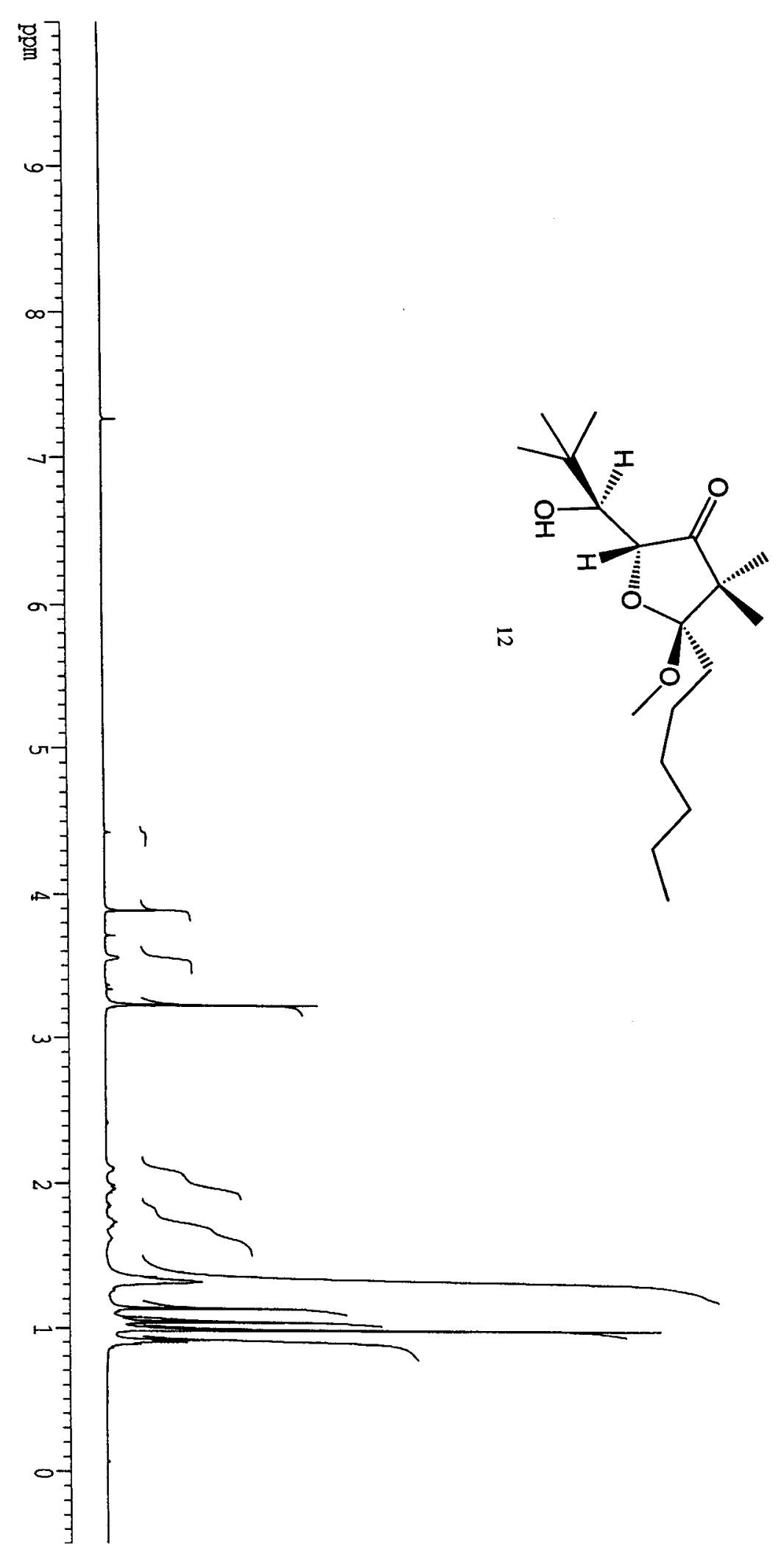




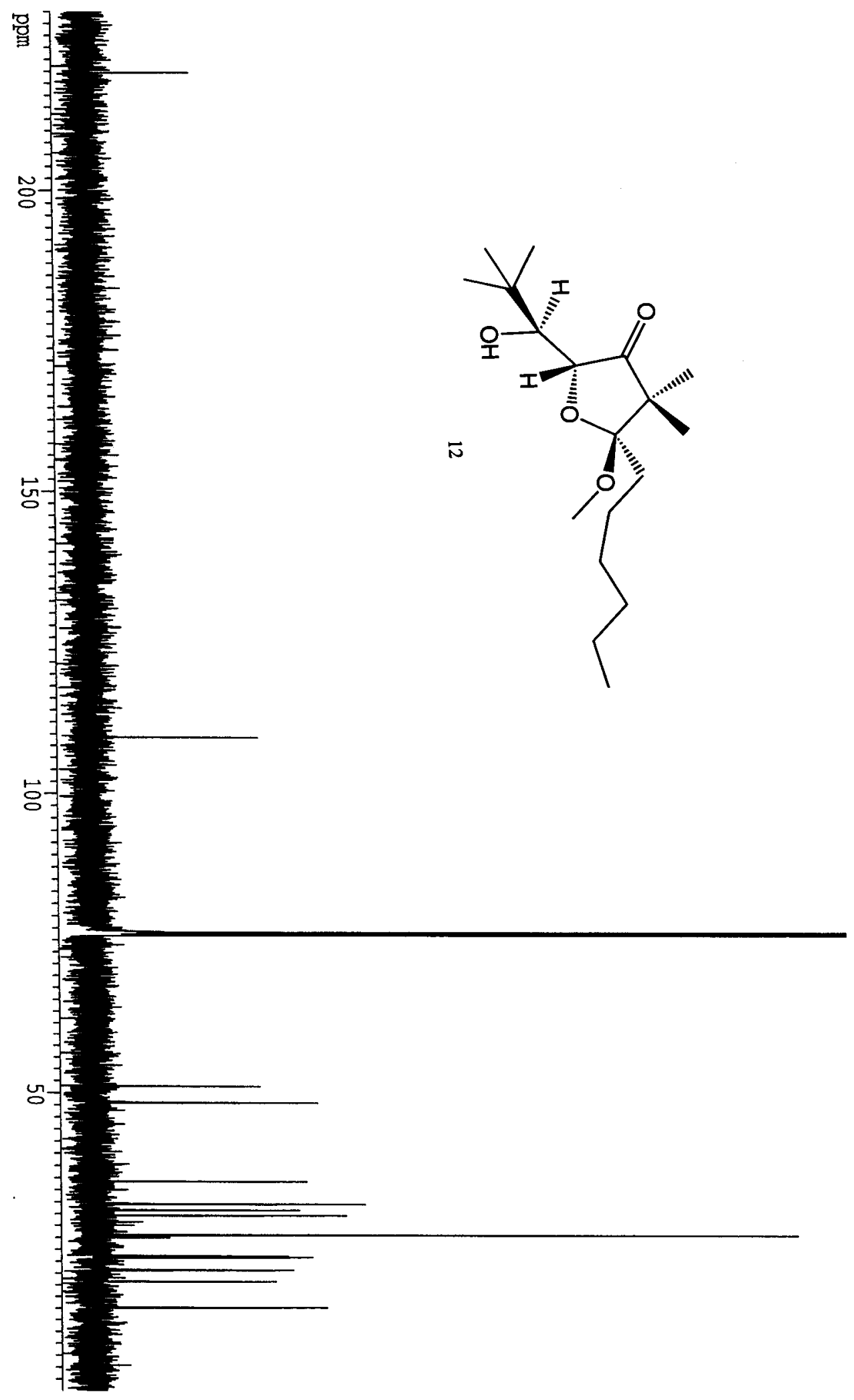

S-29 


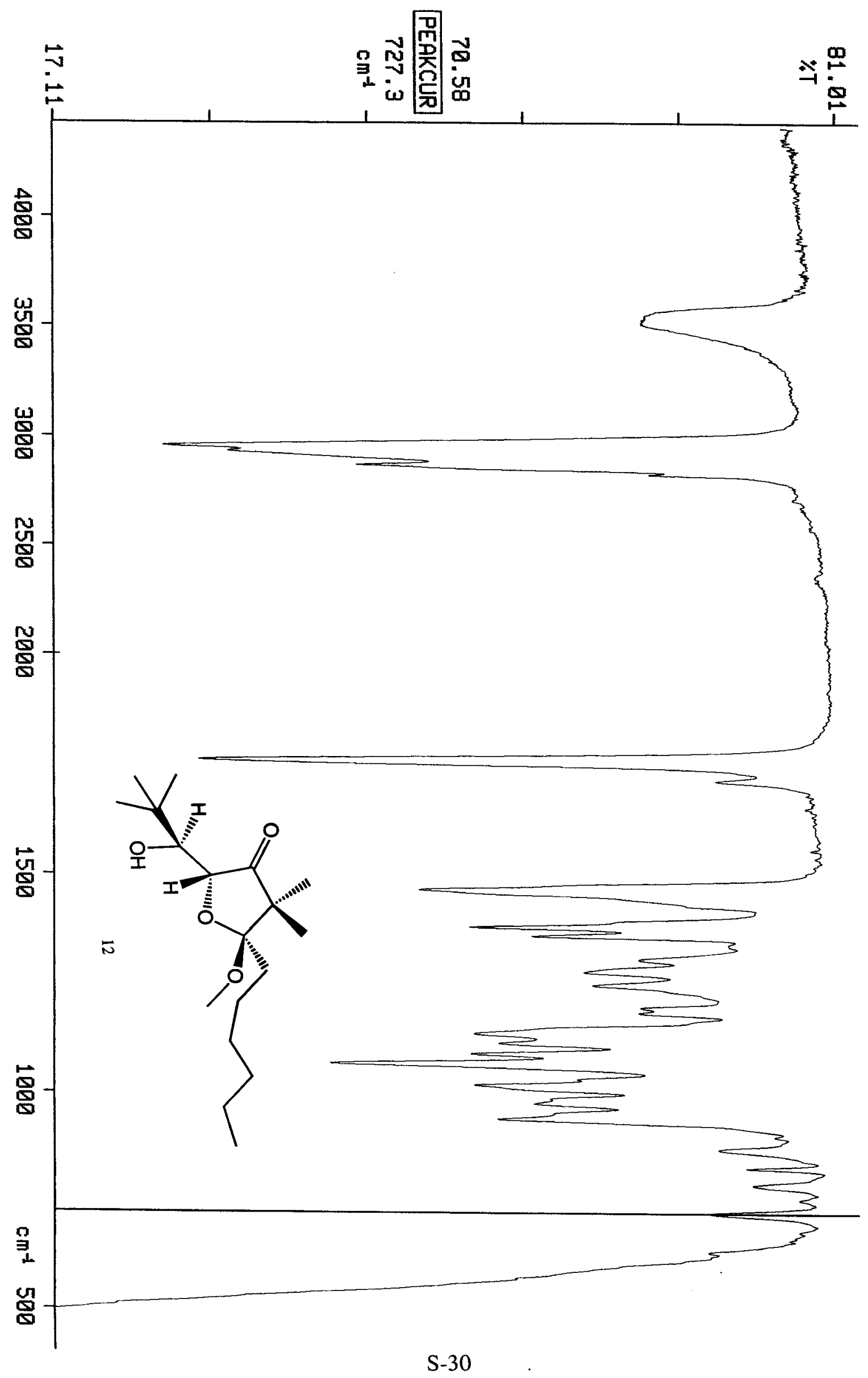




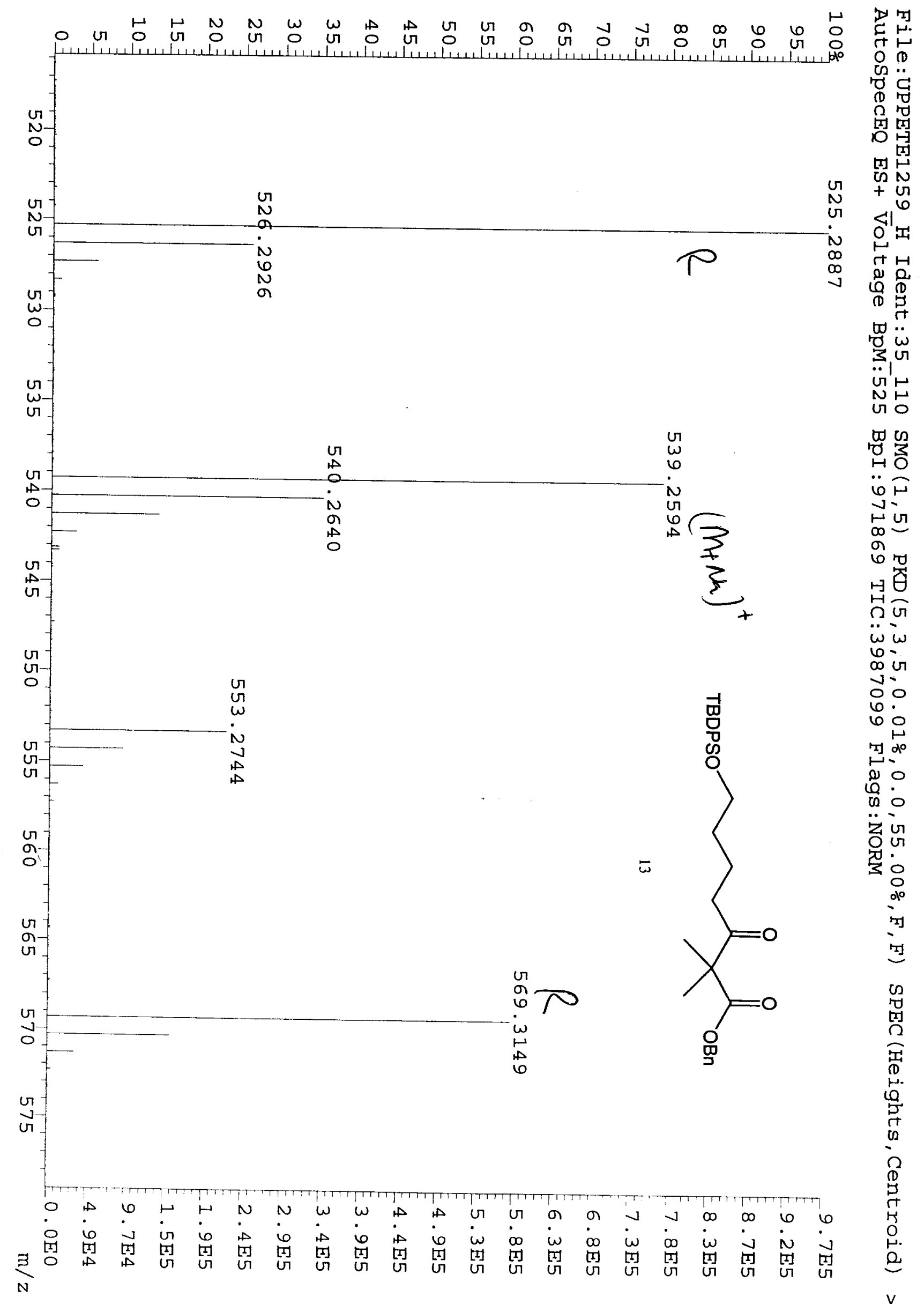




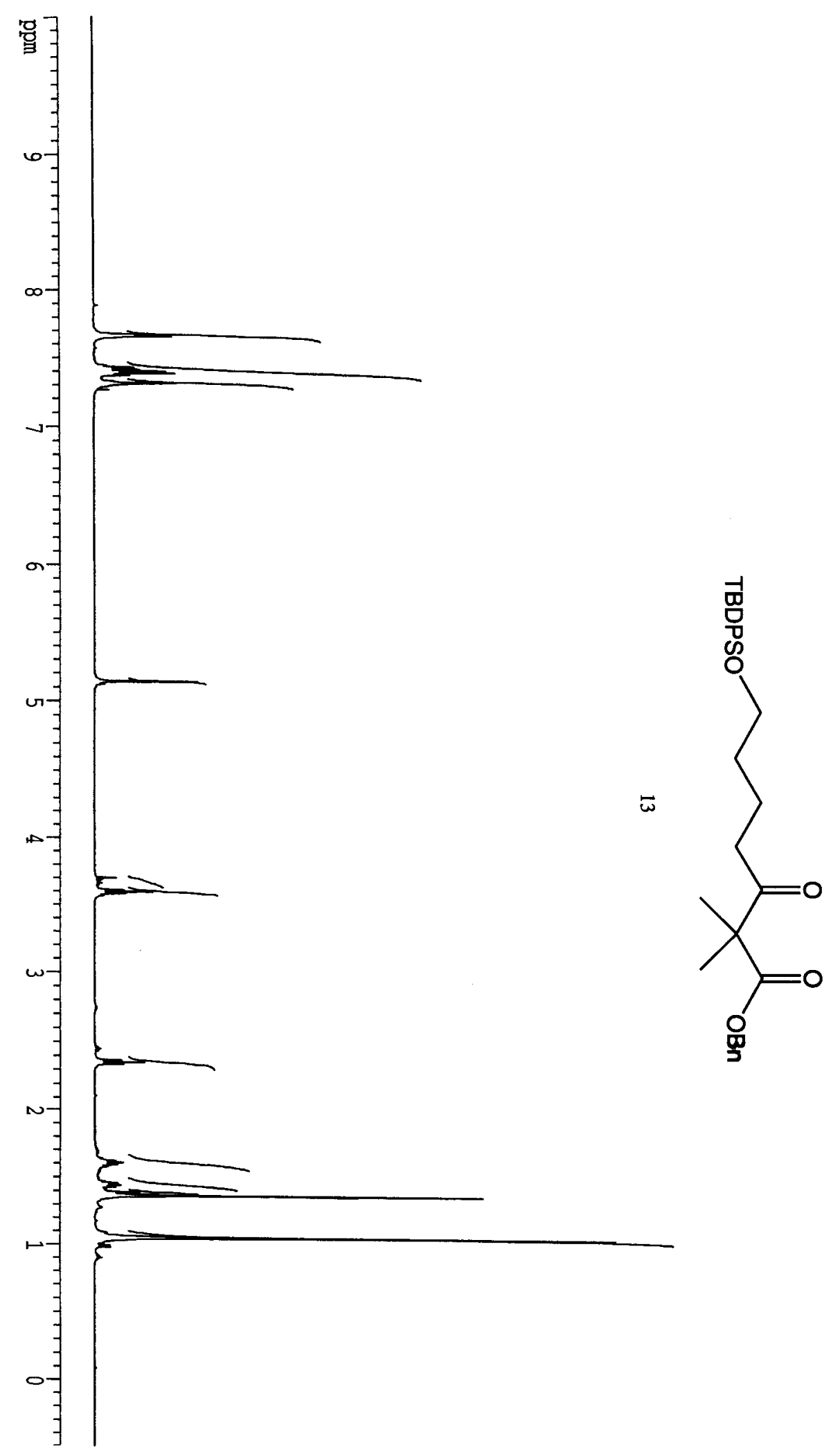




$$
k
$$


ज्ञ

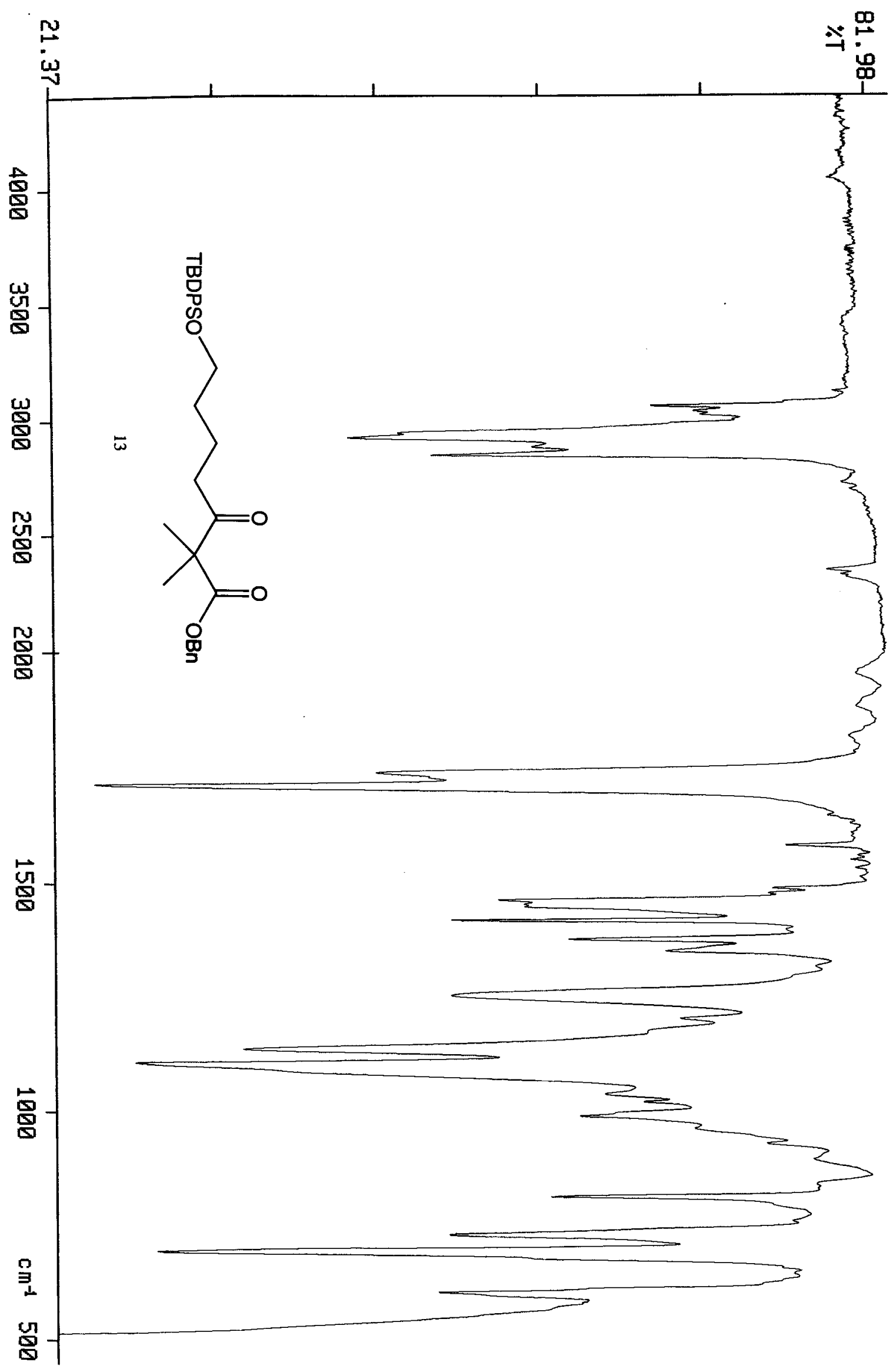




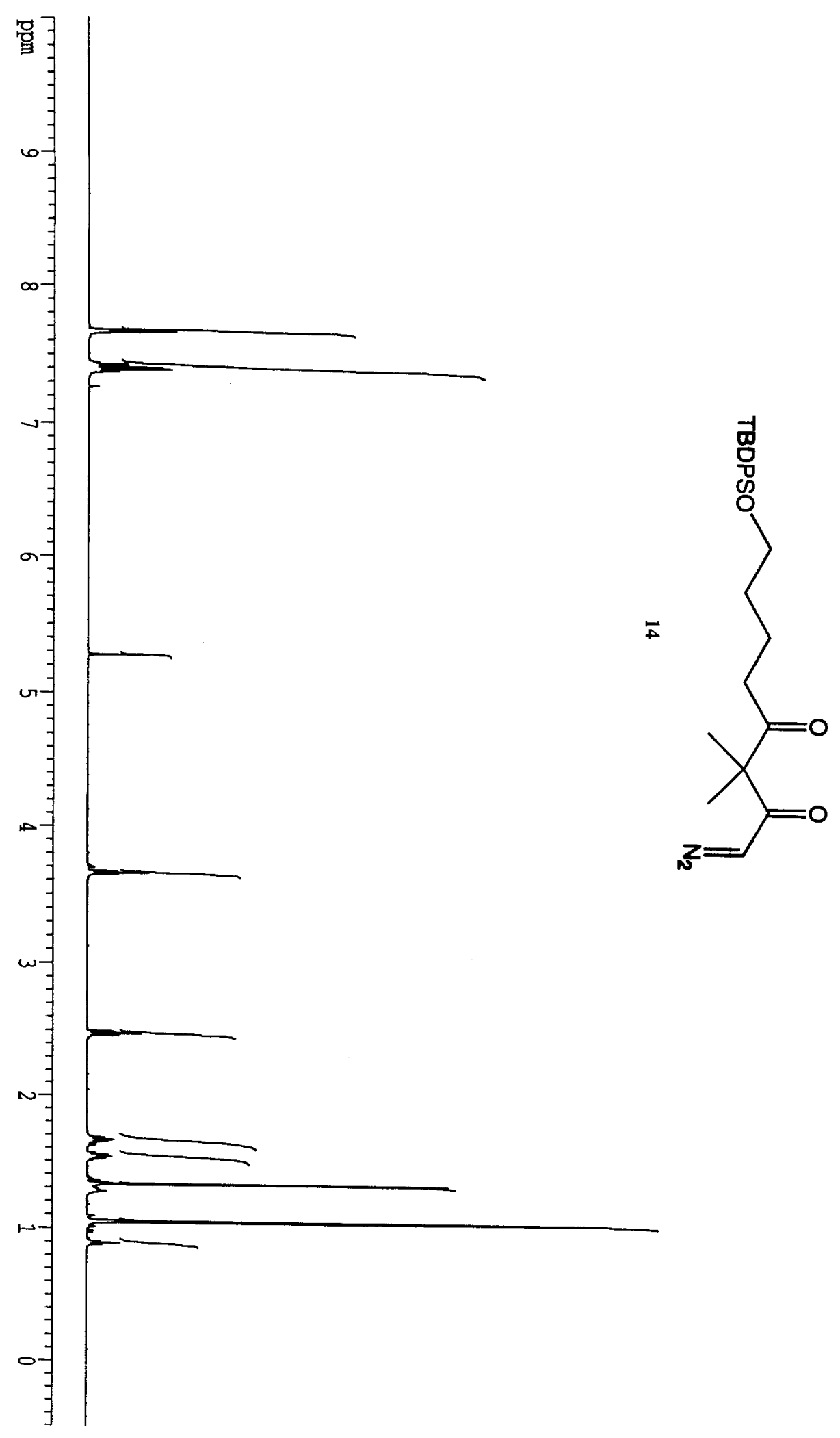




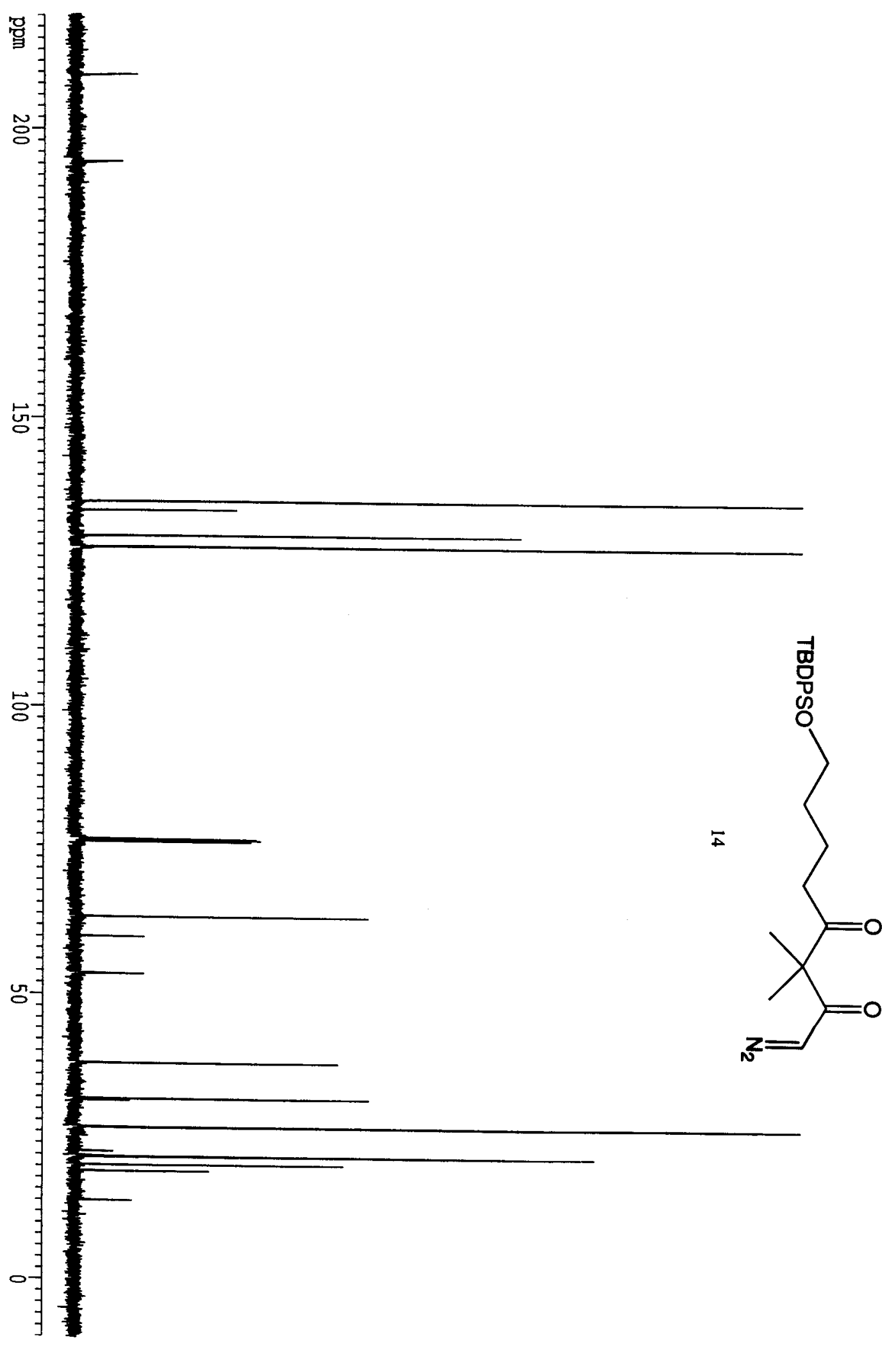




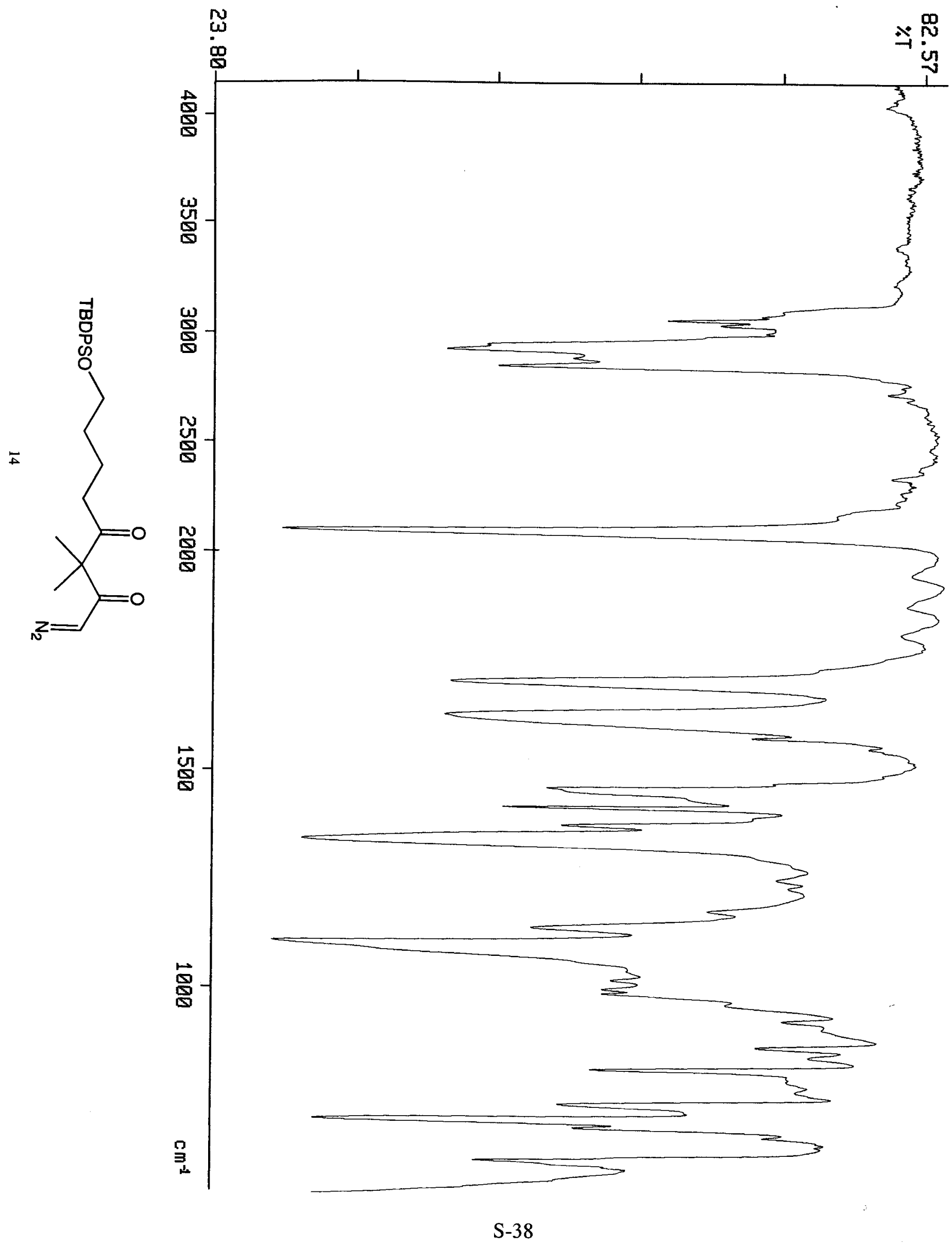





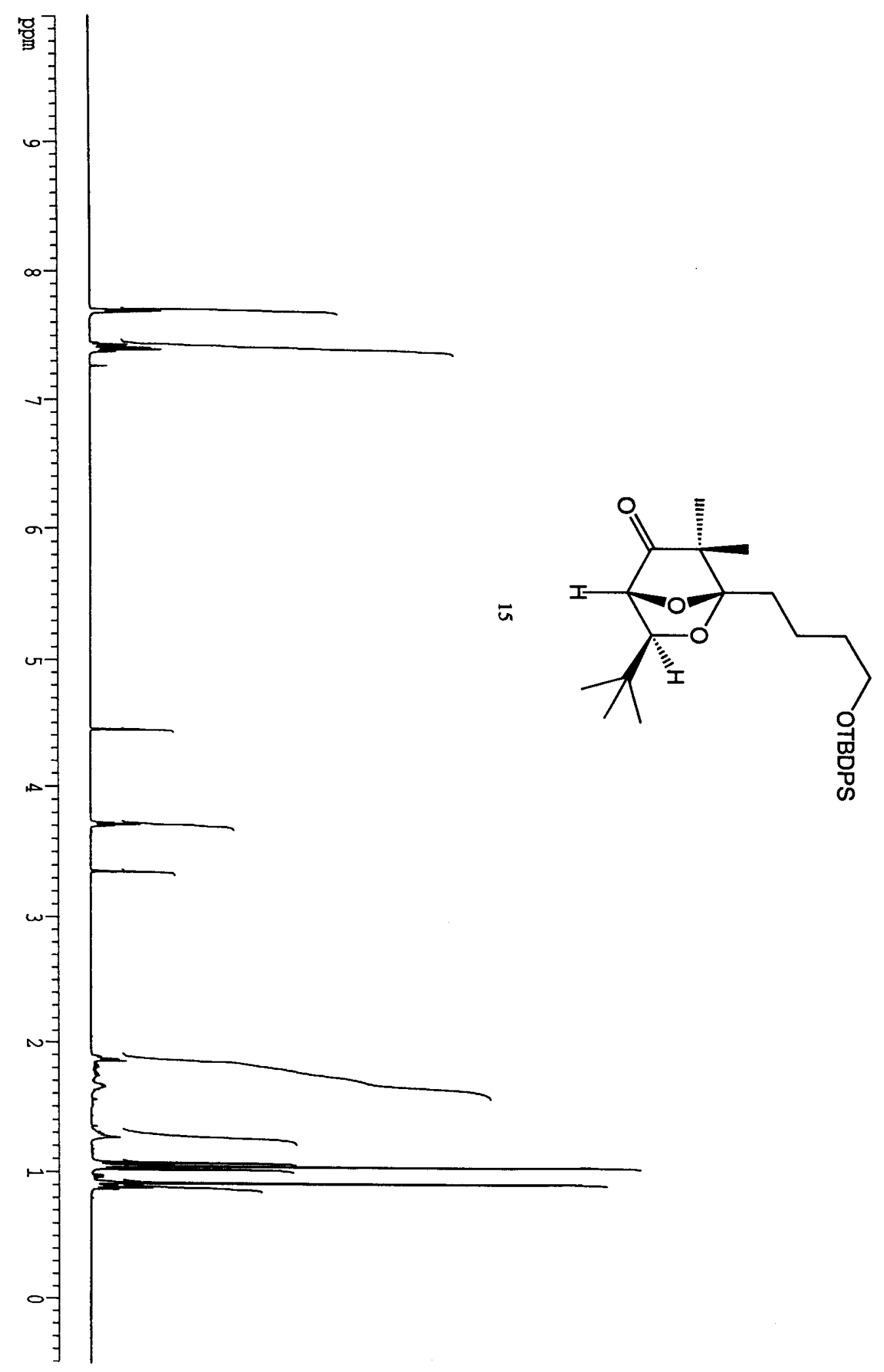




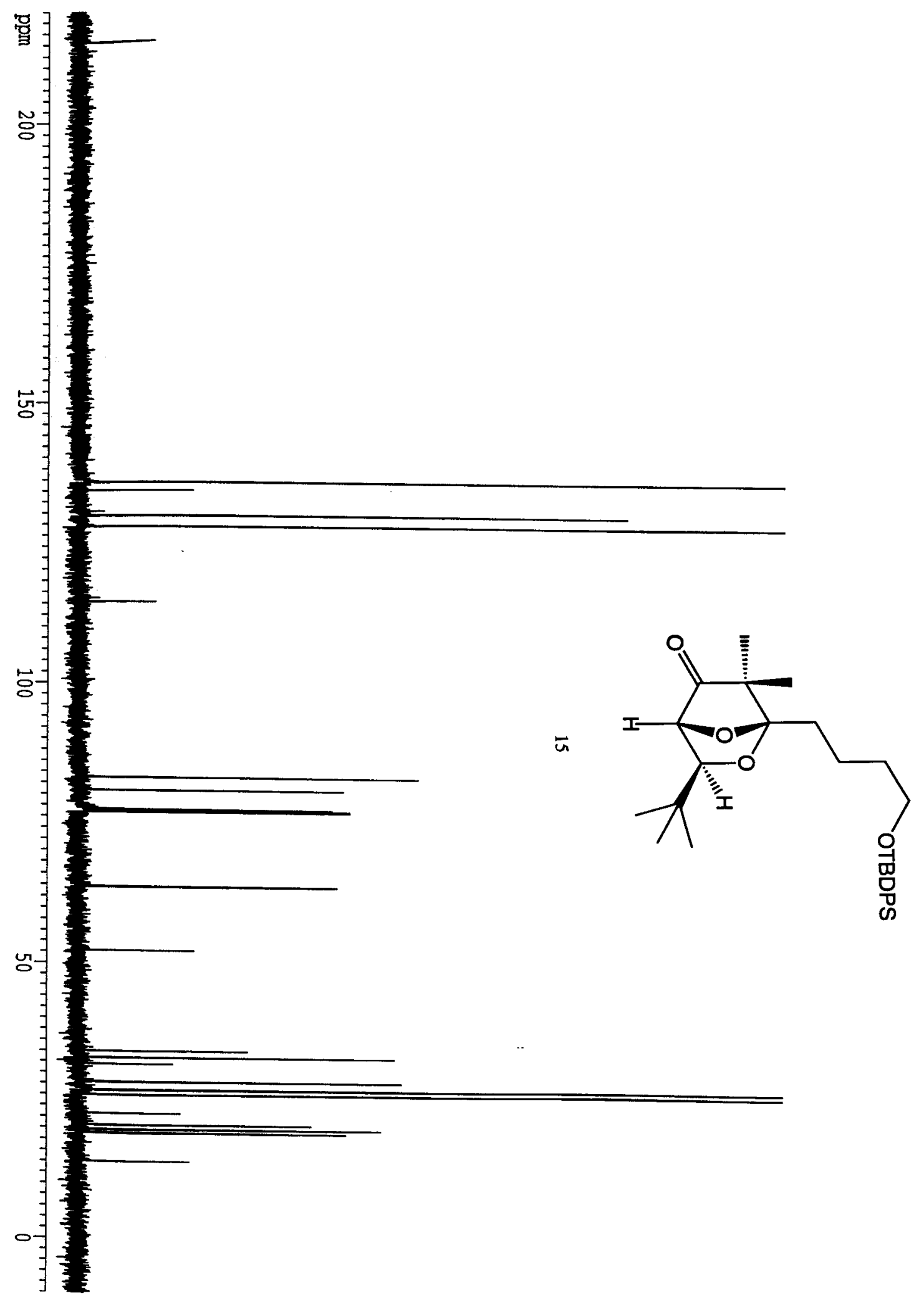




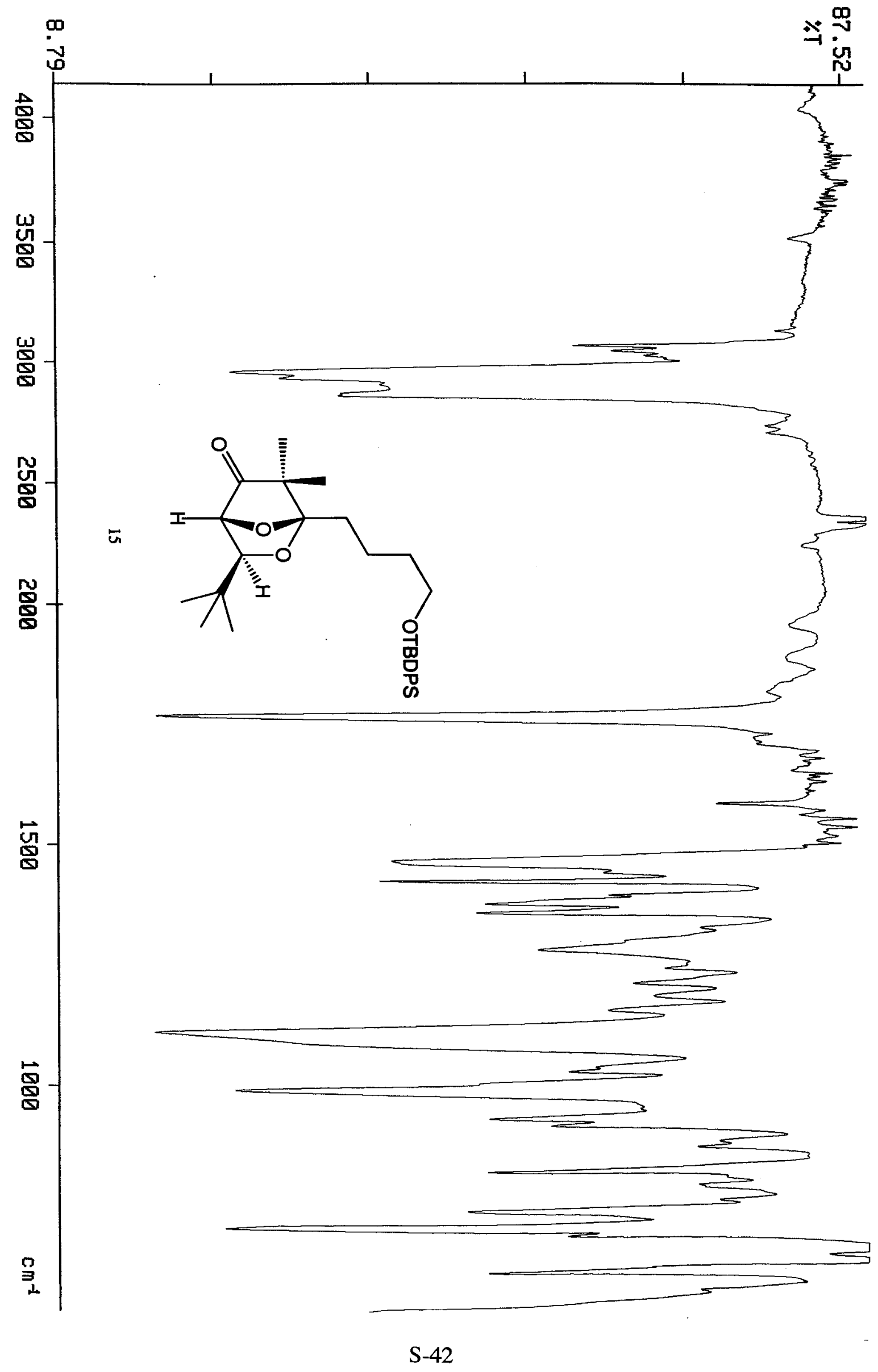




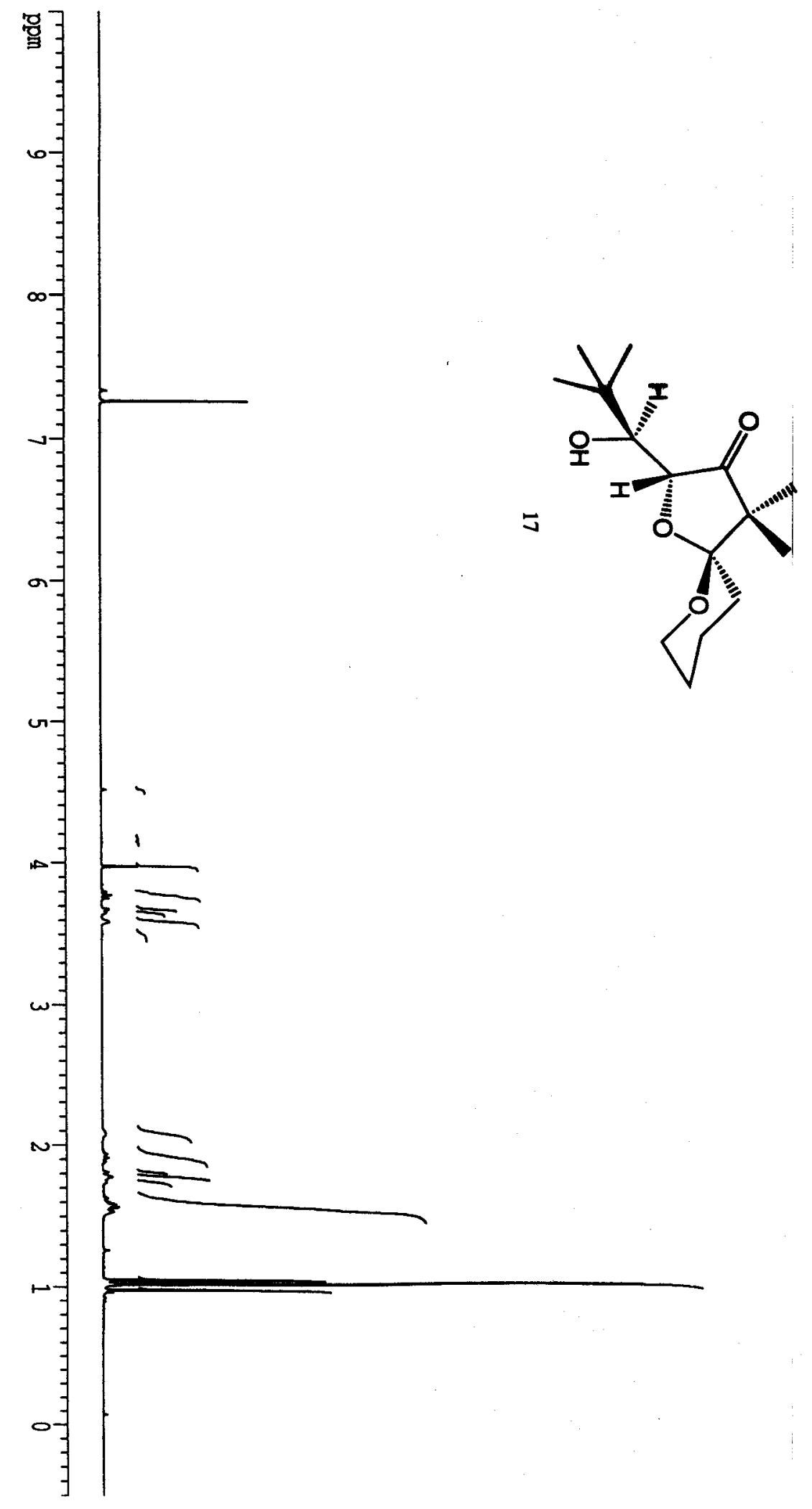




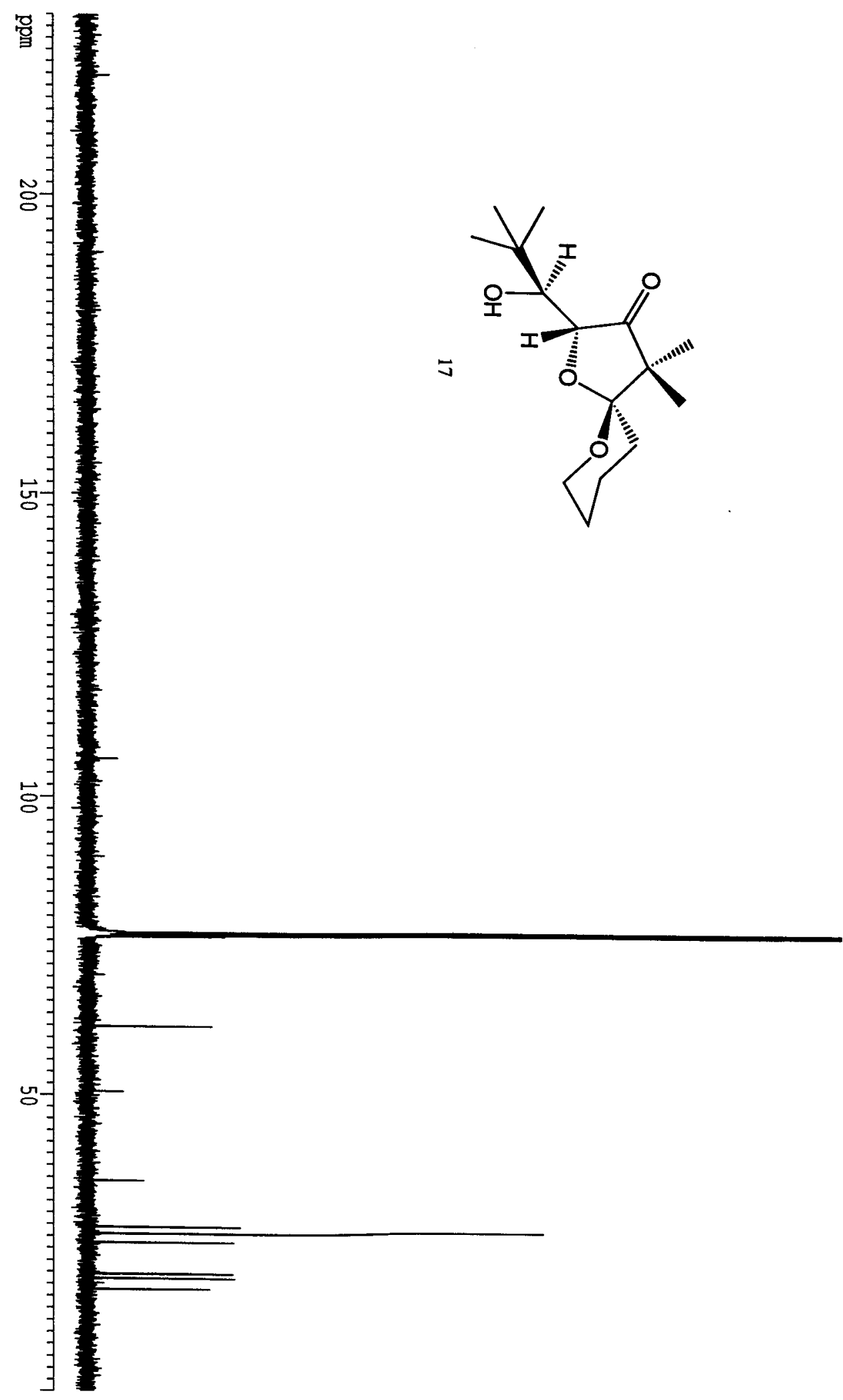




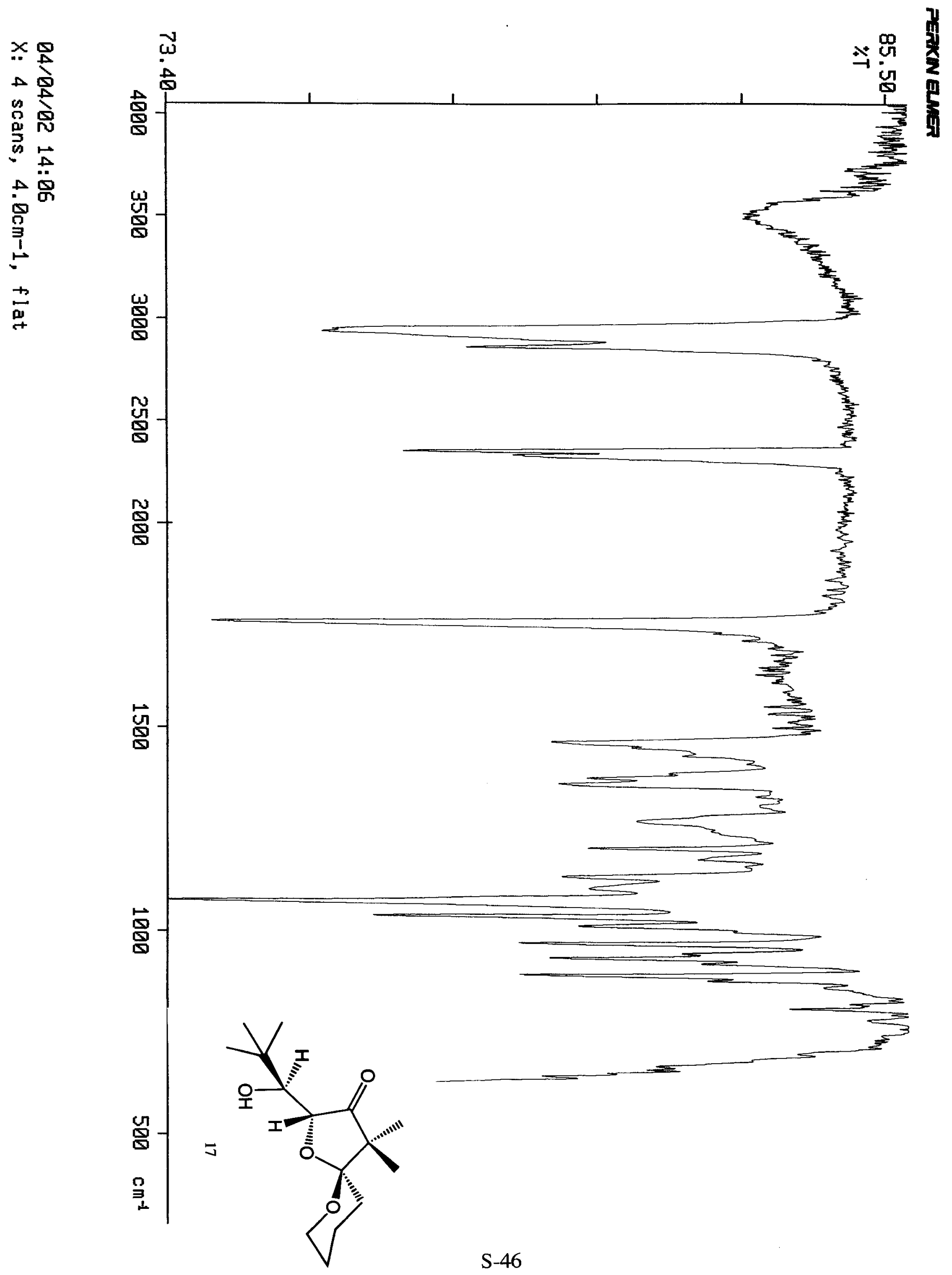




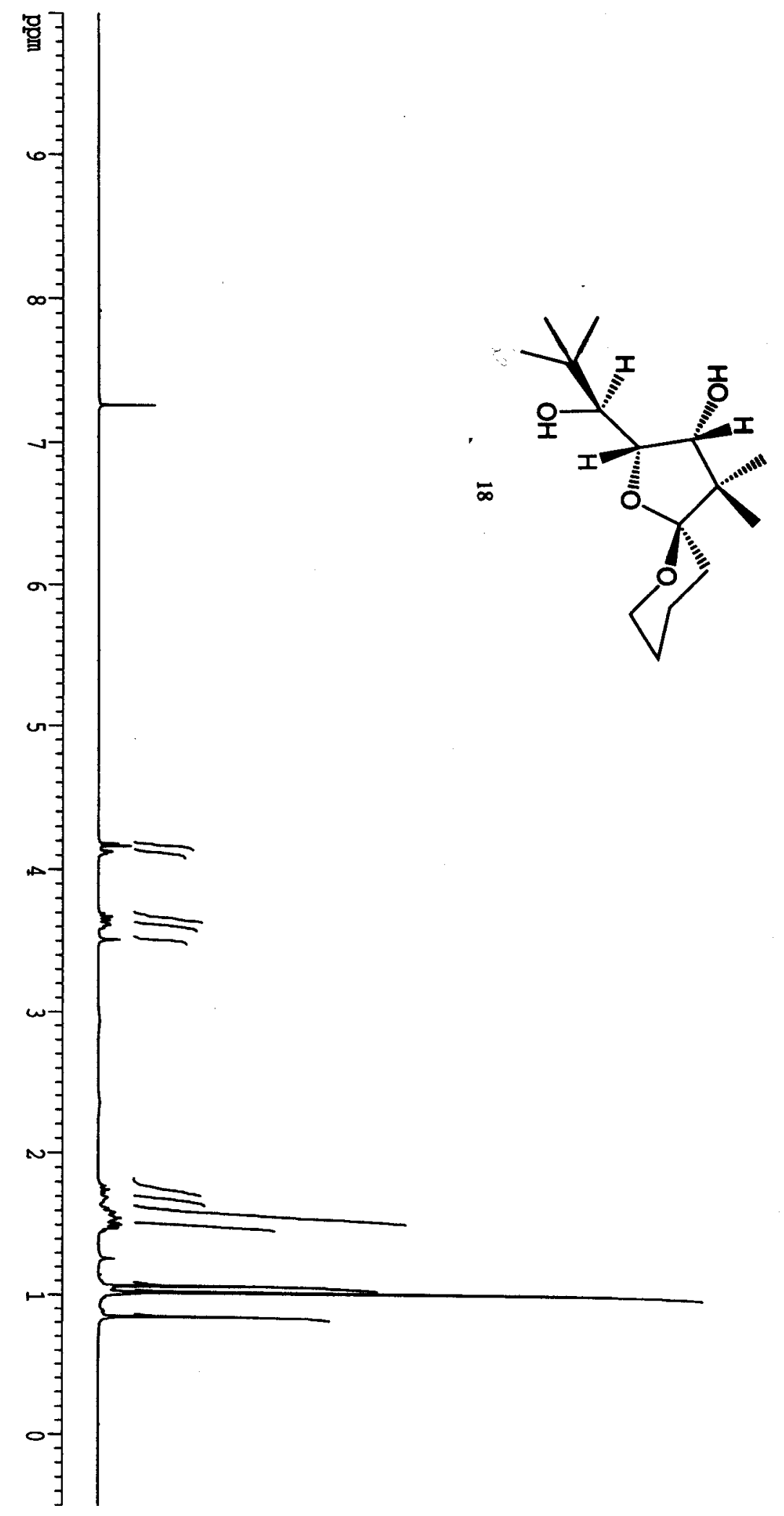




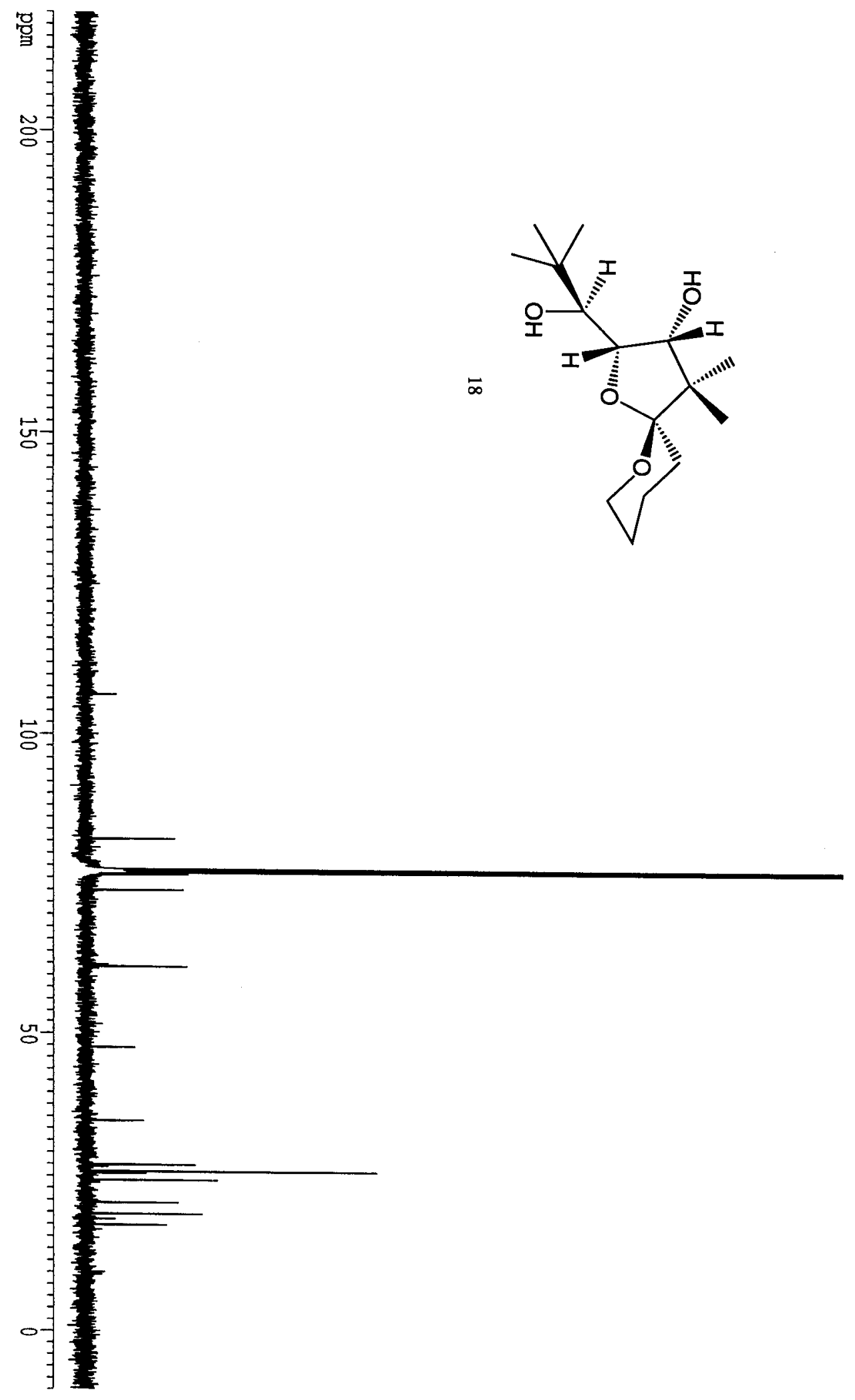




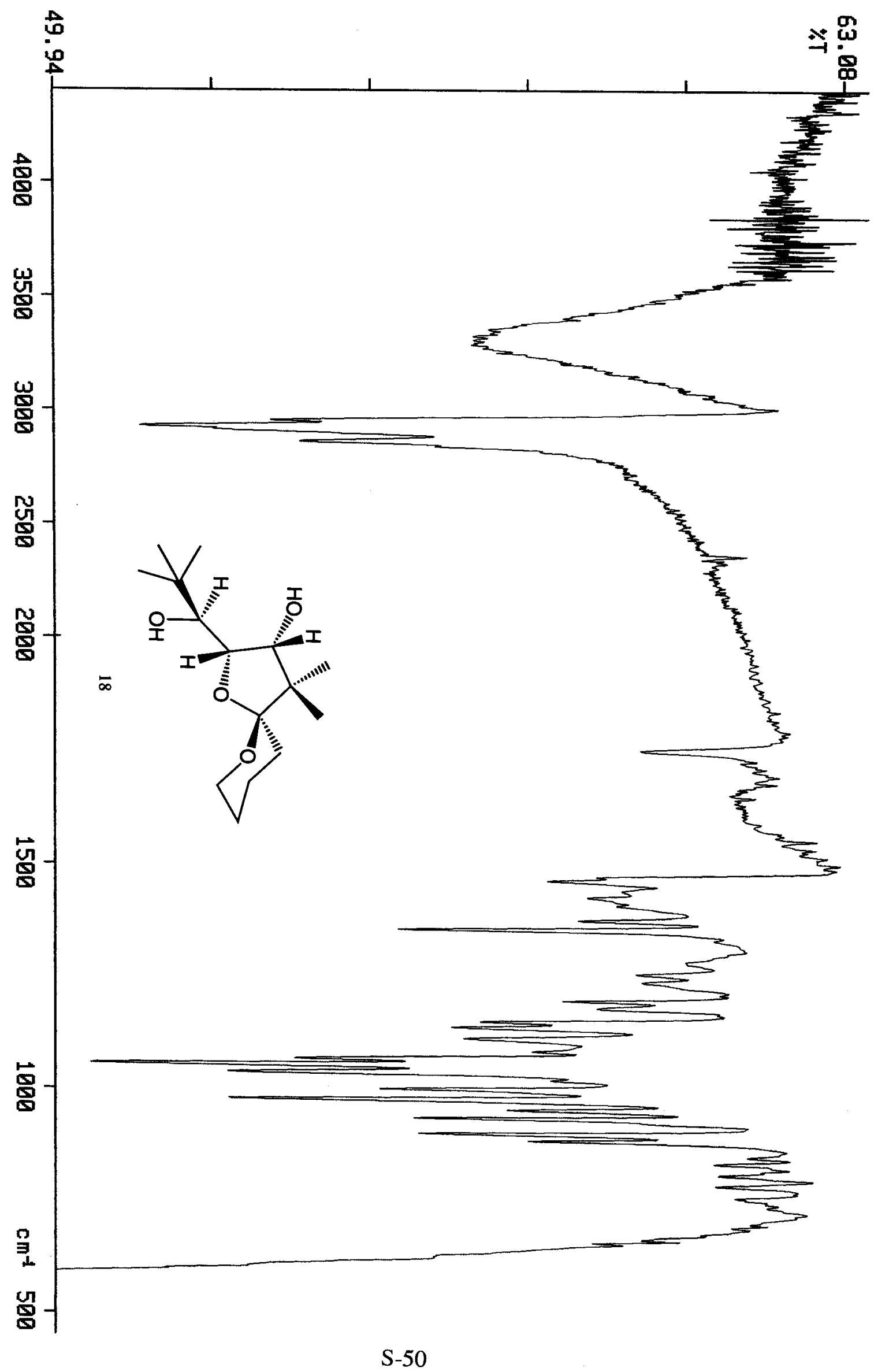




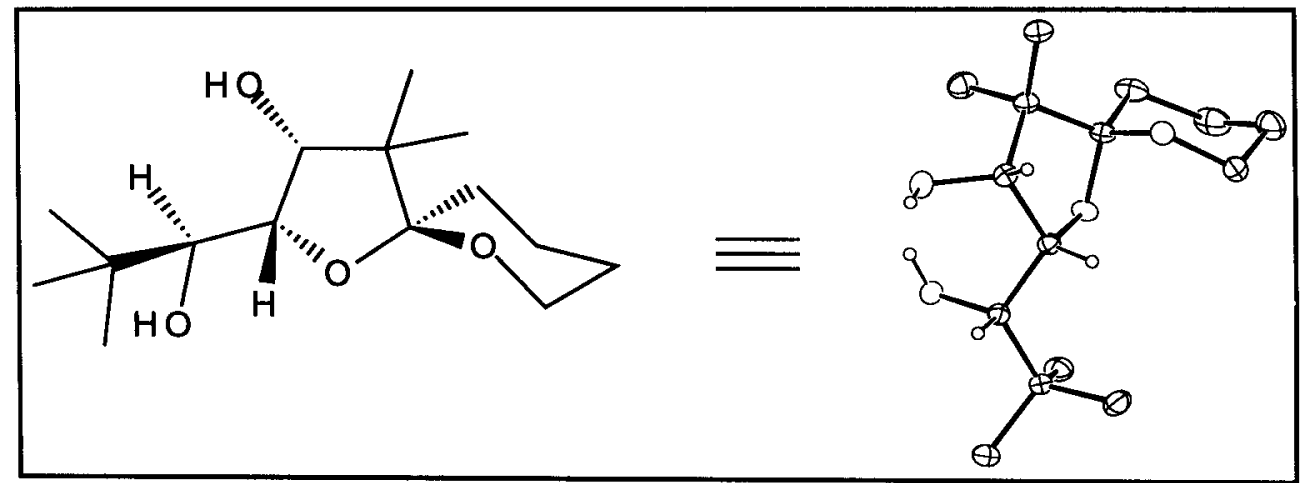

Compound 2027, $\mathrm{C}_{15} \mathrm{H}_{28} \mathrm{O}_{4}$, crystallizes in the monoclinic space group $\mathrm{C} 2 / \mathrm{c}$ (systematic absences $h k l: h+k=0 d d$ and $h 0 l: l=o d d)$ with $a=26.940(3) \AA, b=6.1379(5) \AA, c=19.363(2) \AA, \quad \beta=109.5910(10)^{\circ}$, $V=3016.4(6) \AA^{3}, Z=8$ and $d_{\text {calc }}=1.200 \mathrm{~g} / \mathrm{cm}^{3}$. X-ray intensity data were collected on a Rigaku Mercury CCD area detector employing graphite-monochromated Mo- $K_{\alpha}$ radiation $(\lambda=0.71069 \AA)$ at a temperature of $143^{\circ} \mathrm{K}$. Preliminary indexing was performed from a series of twelve $0.5^{\circ}$ rotation images with exposures of 30 seconds. A total of 326 rotation images were collected with a crystal to detector distance of $36 \mathrm{~mm}$, a $2 \theta$ swing angle of $-10^{\circ}$, rotation widths of $0.5^{\circ}$ and exposures of 100 seconds: scan no. 1 was a $\phi$-scan from $195^{\circ}$ to $358^{\circ}$ at $\omega=10^{\circ}$ and $\chi=20^{\circ}$. Rotation images were processed using CrystalClear', producing a listing of unaveraged $F^{2}$ and $\sigma\left(F^{2}\right)$ values which were then passed to the CrystalStructure $e^{2}$ program package for further processing and structure solution on a Dell Pentium III computer. A total of 6084 reflections were measured over the ranges $6.32 \leq 2 \theta \leq 50.7^{\circ},-24 \leq h \leq 32,-7 \leq k \leq 6,-23 \leq 1 \leq 21$ yielding 2725 unique reflections $\left(R_{\mathrm{int}}=0.0181\right)$. The intensity data were corrected for Lorentz and polarization effects and for absorption. using REQAB ${ }^{3}$ (minimum and maximum transmission 0.803 , 1.000).

The structure was solved by direct methods $\left(\operatorname{SIR} 97^{4}\right)$. Refinement was by full-matrix least squares based on $\mathrm{F}^{2}$ using SHELXL-975. All reflections were used during refinement $\left(\mathrm{F}^{2}\right.$ 's that were experimentally negative were replaced by $\left.F^{2}=0\right)$. The weighting scheme used was $w=1 /\left[\sigma^{2}\left(F_{0}^{2}\right)+\right.$ $\left.0.597 P^{2}+2.0023 P\right]$ where $P=\left(F_{o}^{2}+2 F_{c}^{2}\right) / 3$. Non-hydrogen atoms were refined anisotropically and hydrogen atoms were refined using a "riding" model. Refinement converged to $R_{1}=0.0449$ and 
$w R_{2}=0.1099$ for 2190 reflections for which $F>4 \sigma(F)$ and $R_{1}=0.0579, w R_{2}=0.1212$ and $G O F=1.069$ for all 2725 unique, non-zero reflections and 180 variables $^{6}$. The maximum $\Delta \sigma$ in the final cycle of least squares was 0.000 and the two most prominent peaks in the final difference Fourier were +0.247 and $0.239 \mathrm{e} / \AA^{3}$.

Table 1. lists cell information, data collection parameters, and refinement data. Final positional and equivalent isotropic thermal parameters are given in Table 2. Anisotropic thermal parameters are in Table 3. Tables 4. and 5. list bond distances and bond angles. Figure 1. is an ORTEP ${ }^{7}$ representation of the molecule with $30 \%$ probability thermal ellipsoids displayed.

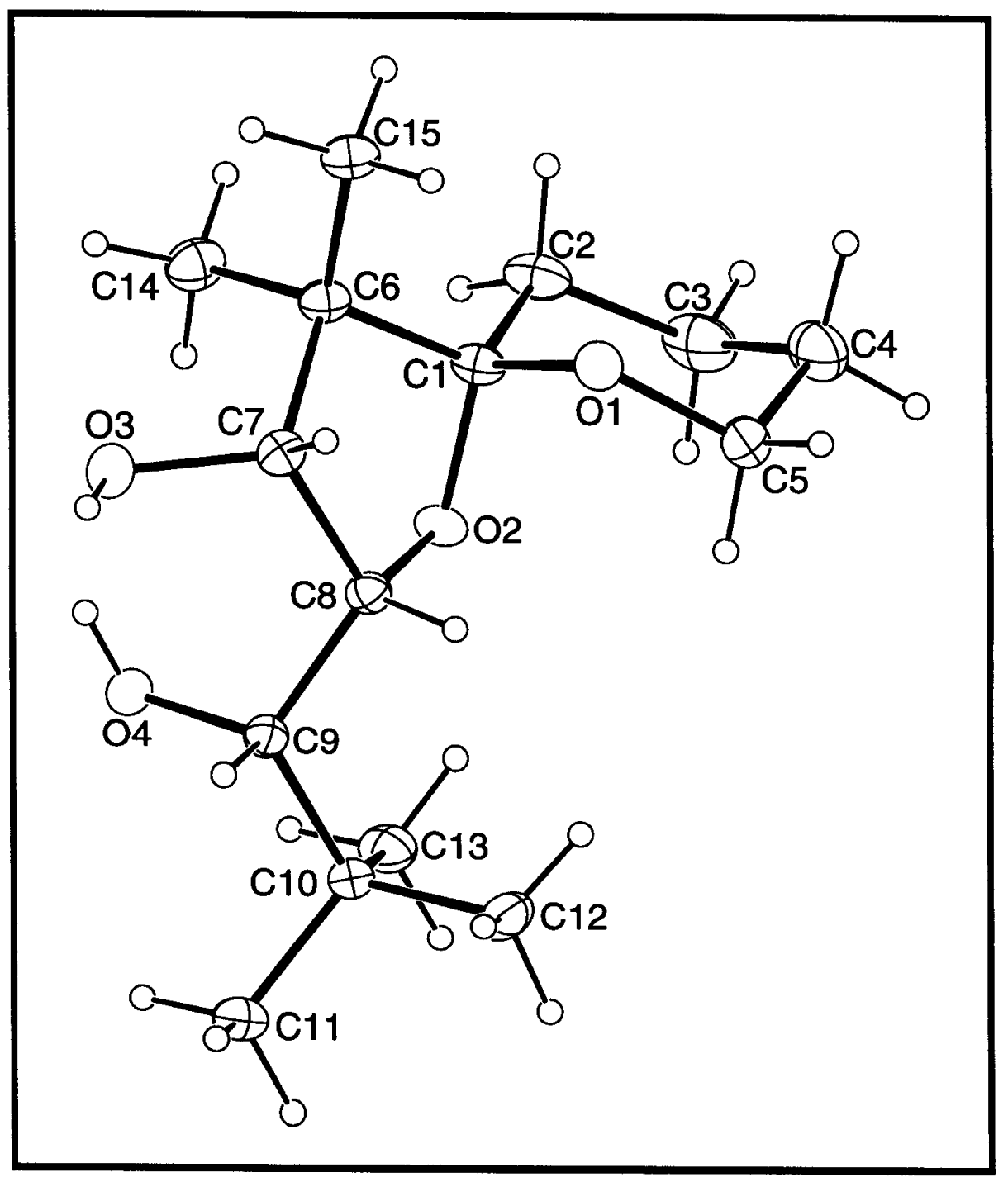

Figure 1. ORTEP drawing of the title compound with $30 \%$ probability thermal ellipsoids. 


\section{References}

1. CrystalClear: Rigaku Corporation, 1999.

2. CrystalStructure: Crystal Structure Analysis Package, Rigaku Corp. Rigaku/MSC (2002).

3. REQAB4: R.A. Jacobsen, (1994). Private Communication.

4. SIR97: Altomare, A., M. Burla, M. Camalli, G. Cascarano, C. Giacovazzo, A. Guagliardi, A. Moliterni, G. Polidori \& R. Spagna (1999). J. Appl. Cryst., 32, 115-119.

5. SHELXL-97: Program for the Refinement of Crystal Structures, Sheldrick, G.M. (1997), University of Göttingen, Germany.

6. $\mathrm{R}_{1}=\sum\left\|\mathrm{F}_{\mathrm{o}}|-| \mathrm{F}_{\mathrm{C}}\right\| / \sum\left|\mathrm{F}_{\mathrm{o}}\right|$

$w R_{2}=\left\{\sum w\left(F_{0}^{2}-F_{c}^{2}\right)^{2} / \sum w\left(F_{0}^{2}\right)^{2}\right\}^{1 / 2}$

GOF $=\left\{\sum w\left(F_{0}^{2}-F_{c}^{2}\right)^{2} /(n-p)\right\}^{1 / 2}$

where $n=$ the number of reflections and $p=$ the number of parameters refined.

7. "ORTEP-II: A Fortran Thermal Ellipsoid Plot Program for Crystal Structure Illustrations". C.K. Johnson (1976) ORNL-5138. 
Formula:

Formula weight:

Crystal class:

Space group:

Z

Cell constants:

a

b

c

$\beta$

V

$\mu$

crystal size, $\mathrm{mm}$

$D_{\text {calc }}$

$F(000)$

Radiation:

$2 \theta$ range

hkl collected:

No. reflections measured:

No. unique reflections:

No. observed reflections

No. reflections used in refinement

No. parameters

$R$ indices $(F>4 \sigma)$

$R$ indices (all data)

GOF:

Final Difference Peaks, e/ $\hat{A}^{3}$
$\mathrm{C}_{15} \mathrm{H}_{28} \mathrm{O}_{4}$

272.37

monoclinic

C2/c (\#15)

8

$26.940(3) \AA$
$6.1379(5) \AA$
$19.363(2) \AA$
$109.5910(10)^{\circ}$
$3016.4(6) \AA^{3}$
$0.85 \mathrm{~cm}^{-1}$
$0.48 \times 0.12 \times 0.03$
$1.200 \mathrm{~g} / \mathrm{cm}^{3}$
1200
$M 0-K_{\alpha}(\lambda=0.71069 \AA)$
$6.32-50.7 \circ$
$-24 \leq h \leq 32 ;-7 \leq k \leq 6 ;-23 \leq \mathrm{l} \leq 21$
6084
$2725\left(R_{\text {int }}=0.0181\right)$
$2190(F>4 \sigma)$
2725
180
$R_{1}=0.0449$
$w R_{2}=0.1099$
$R_{1}=0.0579$
$w R_{2}=0.1212$
1.069
$+0.247,-0.239$


Table 2. Refined Positional Parameters for Compound 2027

\begin{tabular}{|c|c|c|c|c|}
\hline Atom & $x$ & $y$ & $z$ & $\mathrm{U}_{\mathrm{ea}}, \AA^{2}$ \\
\hline $\mathrm{C1}$ & $0.41341(6)$ & $0.7089(3)$ & $0.36597(8)$ & $0.0271(4)$ \\
\hline $\mathrm{C} 2$ & $0.46942(7)$ & $0.7850(3)$ & $0.40508(9)$ & $0.0375(4)$ \\
\hline $\mathrm{H} 2 \mathrm{a}$ & 0.4804 & 0.7386 & 0.4559 & 0.050 \\
\hline $\mathrm{H} 2 \mathrm{~b}$ & 0.4705 & 0.9430 & 0.4043 & 0.050 \\
\hline $\mathrm{C} 3$ & $0.50762(7)$ & $0.6938(4)$ & $0.36910(11)$ & $0.0510(6)$ \\
\hline $\mathrm{H} 3 \mathrm{a}$ & 0.5013 & 0.7640 & 0.3220 & 0.068 \\
\hline $\mathrm{H} 3 \mathrm{~b}$ & 0.5435 & 0.7261 & 0.3997 & 0.068 \\
\hline $\mathrm{C} 4$ & $0.50117(8)$ & $0.4499(4)$ & $0.35816(12)$ & $0.0512(6)$ \\
\hline $\mathrm{H} 4 \mathrm{a}$ & 0.5226 & 0.3988 & 0.3299 & 0.068 \\
\hline $\mathrm{H} 4 \mathrm{~b}$ & 0.5130 & 0.3772 & 0.4054 & 0.068 \\
\hline C5 & $0.44432(7)$ & $0.3959(3)$ & $0.31850(10)$ & $0.0383(5)$ \\
\hline $\mathrm{H} 5 \mathrm{a}$ & 0.4333 & 0.4600 & 0.2699 & 0.051 \\
\hline $\mathrm{H} 5 \mathrm{~b}$ & 0.4402 & 0.2392 & 0.3131 & 0.051 \\
\hline C6 & $0.37076(6)$ & $0.7667(3)$ & $0.39971(8)$ & $0.0264(4)$ \\
\hline $\mathrm{C7}$ & $0.32065(6)$ & $0.7299(3)$ & $0.33203(8)$ & $0.0257(4)$ \\
\hline $\mathrm{H} 7$ & 0.3077 & 0.5817 & 0.3340 & 0.034 \\
\hline C8 & $0.33999(6)$ & $0.7483(3)$ & $0.26483(8)$ & $0.0238(4)$ \\
\hline $\mathrm{H8}$ & 0.3380 & 0.6027 & 0.2433 & 0.032 \\
\hline C9 & $0.30902(6)$ & $0.9026(3)$ & $0.20440(8)$ & $0.0244(4)$ \\
\hline $\mathrm{H} 9$ & 0.2727 & 0.8486 & 0.1870 & 0.032 \\
\hline C10 & $0.32635(6)$ & $0.9190(3)$ & $0.13612(8)$ & $0.0268(4)$ \\
\hline C11 & $0.28198(7)$ & $1.0305(3)$ & $0.07474(9)$ & $0.0383(5)$ \\
\hline $\mathrm{H} 11 \mathrm{a}$ & 0.2914 & 1.0373 & 0.0311 & 0.057 \\
\hline H11b & 0.2768 & 1.1754 & 0.0897 & 0.057 \\
\hline H11c & 0.2500 & 0.9485 & 0.0650 & 0.057 \\
\hline $\mathrm{C} 12$ & $0.33435(8)$ & $0.6909(3)$ & $0.11029(10)$ & $0.0401(5)$ \\
\hline $\mathrm{H} 12 \mathrm{a}$ & 0.3401 & 0.7006 & 0.0641 & 0.060 \\
\hline $\mathrm{H} 12 \mathrm{~b}$ & 0.3036 & 0.6043 & 0.1047 & 0.060 \\
\hline $\mathrm{H} 12 \mathrm{c}$ & 0.3644 & 0.6243 & 0.1458 & 0.060 \\
\hline $\mathrm{C} 13$ & $0.37678(7)$ & $1.0514(3)$ & $0.15120(10)$ & $0.0354(4)$ \\
\hline $\mathrm{H} 13 \mathrm{a}$ & 0.4047 & 0.9838 & 0.1900 & 0.053 \\
\hline $\mathrm{H} 13 \mathrm{~b}$ & 0.3712 & 1.1966 & 0.1655 & 0.053 \\
\hline $\mathrm{H} 13 \mathrm{c}$ & 0.3863 & 1.0571 & 0.1076 & 0.053 \\
\hline C14 & $0.37560(8)$ & $1.0050(3)$ & $0.42381(10)$ & $0.0370(4)$ \\
\hline $\mathrm{H} 14 \mathrm{a}$ & 0.4070 & 1.0240 & 0.4654 & 0.055 \\
\hline $\mathrm{H} 14 \mathrm{~b}$ & 0.3454 & 1.0452 & 0.4368 & 0.055 \\
\hline $\mathrm{H} 14 \mathrm{c}$ & 0.3774 & 1.0956 & 0.3843 & 0.055 \\
\hline C15 & $0.37112(7)$ & $0.6202(3)$ & $0.46366(9)$ & $0.0337(4)$ \\
\hline $\mathrm{H} 15 \mathrm{a}$ & 0.4037 & 0.6393 & 0.5034 & 0.050 \\
\hline
\end{tabular}




\begin{tabular}{|lllll|}
\hline $\mathrm{H} 15 \mathrm{~b}$ & 0.3677 & 0.4708 & 0.4481 & 0.050 \\
$\mathrm{H} 15 \mathrm{c}$ & 0.3422 & 0.6585 & 0.4797 & 0.050 \\
$\mathrm{O} 1$ & $0.41196(4)$ & $0.4776(2)$ & $0.35828(6)$ & $0.0297(3)$ \\
$\mathrm{O} 2$ & $0.39476(4)$ & $0.8068(2)$ & $0.29513(6)$ & $0.0267(3)$ \\
$\mathrm{O} 3$ & $0.27995(4)$ & $0.8819(2)$ & $0.33111(6)$ & $0.0316(3)$ \\
$\mathrm{H} 3$ & 0.2511 & 0.8229 & 0.3139 & 0.047 \\
$\mathrm{O} 4$ & $0.30696(5)$ & $1.1186(2)$ & $0.23195(6)$ & $0.0305(3)$ \\
$\mathrm{H} 4$ & 0.2991 & 1.1117 & 0.2693 & 0.046 \\
\hline \multicolumn{4}{|l}{} \\
$\mathrm{U}_{\mathrm{eq}}=1 / 3\left[\mathrm{U}_{11}\left(\mathrm{aa}^{*}\right)^{2}+\mathrm{U}_{22}\left(\mathrm{bb}^{\star}\right)^{2}+\mathrm{U}_{33}\left(\mathrm{cc}^{\star}\right)^{2}+2 \mathrm{U}_{12} \mathrm{aa}^{*} \mathrm{bb}^{*} \cos \gamma+2 \mathrm{U}_{13} \mathrm{aa}^{*} \mathrm{cc} \cos \beta+2 \mathrm{U}_{23} \mathrm{bb}^{*} \mathrm{cc} \cos \alpha\right]$ \\
\hline
\end{tabular}


Table 3. Refined Thermal Parameters (U's) for Compound 2027

\begin{tabular}{|c|c|c|c|c|c|c|}
\hline Atom & $U_{11}$ & $\mathrm{U}_{22}$ & $\mathrm{U}_{33}$ & $\mathrm{U}_{23}$ & $\mathrm{U}_{13}$ & $\mathrm{U}_{12}$ \\
\hline $\mathrm{C} 1$ & $0.0277(8)$ & $0.0312(9)$ & $0.0206(8)$ & $0.0053(7)$ & $0.0056(6)$ & $-0.0026(7)$ \\
\hline $\mathrm{C} 2$ & $0.0306(9)$ & $0.0495(11)$ & $0.0274(9)$ & $0.0068(8)$ & $0.0030(7)$ & $-0.0090(8)$ \\
\hline C3 & $0.0253(9)$ & $0.083(2)$ & $0.0414(11)$ & $0.0110(11)$ & $0.0074(8)$ & $-0.0061(10)$ \\
\hline $\mathrm{C} 4$ & $0.0357(11)$ & $0.076(2)$ & $0.0444(11)$ & $0.0125(11)$ & $0.0163(9)$ & $0.0162(11)$ \\
\hline C5 & $0.0395(10)$ & $0.0456(11)$ & $0.0319(9)$ & $0.0070(9)$ & $0.0149(8)$ & $0.0137(9)$ \\
\hline C6 & $0.0301(9)$ & $0.0265(8)$ & $0.0221(8)$ & $0.0007(7)$ & $0.0082(7)$ & $-0.0040(7)$ \\
\hline $\mathrm{C} 7$ & $0.0273(8)$ & $0.0252(8)$ & $0.0261(8)$ & $-0.0002(7)$ & $0.0108(7)$ & $-0.0032(7)$ \\
\hline $\mathrm{C} 8$ & $0.0216(8)$ & $0.0267(8)$ & $0.0223(8)$ & $-0.0015(7)$ & $0.0065(6)$ & $-0.0018(7)$ \\
\hline C9 & $0.0229(8)$ & $0.0262(8)$ & $0.0231(8)$ & $-0.0015(7)$ & $0.0067(6)$ & $0.0003(7)$ \\
\hline $\mathrm{C} 10$ & $0.0291(8)$ & $0.0299(9)$ & $0.0209(8)$ & $-0.0002(7)$ & $0.0075(7)$ & $0.0034(7)$ \\
\hline C11 & $0.0394(10)$ & $0.0499(12)$ & $0.0237(9)$ & $0.0053(8)$ & $0.0078(8)$ & $0.0094(9)$ \\
\hline $\mathrm{C} 12$ & $0.0564(12)$ & $0.0367(10)$ & $0.0294(9)$ & $-0.0053(8)$ & $0.0175(9)$ & $0.0040(9)$ \\
\hline C13 & $0.0359(10)$ & $0.0425(10)$ & $0.0300(9)$ & $0.0063(8)$ & $0.0137(8)$ & $-0.0011(8)$ \\
\hline $\mathrm{C} 14$ & $0.0437(10)$ & $0.0332(10)$ & $0.0334(9)$ & $-0.0056(8)$ & $0.0121(8)$ & $-0.0072(8)$ \\
\hline C15 & $0.0386(10)$ & $0.0383(10)$ & $0.0247(8)$ & $0.0028(8)$ & $0.0115(7)$ & $-0.0031(8)$ \\
\hline 01 & $0.0311(6)$ & $0.0310(6)$ & $0.0281(6)$ & $0.0033(5)$ & $0.0116(5)$ & $0.0028(5)$ \\
\hline $\mathrm{O} 2$ & $0.0226(6)$ & $0.0340(6)$ & $0.0219(6)$ & $0.0060(5)$ & $0.0054(5)$ & $-0.0024(5)$ \\
\hline $\mathrm{O} 3$ & $0.0278(6)$ & $0.0344(7)$ & $0.0363(7)$ & $-0.0002(6)$ & $0.0157(5)$ & $0.0013(5)$ \\
\hline O4 & $0.0382(7)$ & $0.0285(6)$ & $0.0252(6)$ & $-0.0011(5)$ & $0.0111(5)$ & $0.0064(5)$ \\
\hline
\end{tabular}


Table 4. Bond Distances In Compound 2027, $\AA$

\begin{tabular}{|llllll|}
\hline $\mathrm{C} 1-\mathrm{O} 2$ & $1.426(2)$ & $\mathrm{C} 1-\mathrm{O} 1$ & $1.427(2)$ & $\mathrm{C} 1-\mathrm{C} 2$ & $1.517(2)$ \\
$\mathrm{C} 1-\mathrm{C} 6$ & $1.542(2)$ & $\mathrm{C} 2-\mathrm{C} 3$ & $1.529(3)$ & $\mathrm{C} 3-\mathrm{C} 4$ & $1.514(3)$ \\
$\mathrm{C} 4-\mathrm{C} 5$ & $1.502(3)$ & $\mathrm{C} 5-\mathrm{O} 1$ & $1.433(2)$ & $\mathrm{C} 6-\mathrm{C} 14$ & $1.527(2)$ \\
$\mathrm{C} 6-\mathrm{C} 15$ & $1.528(2)$ & $\mathrm{C} 6-\mathrm{C} 7$ & $1.551(2)$ & $\mathrm{C} 7-\mathrm{O} 3$ & $1.435(2)$ \\
$\mathrm{C} 7-\mathrm{C} 8$ & $1.560(2)$ & $\mathrm{C} 8-\mathrm{O} 2$ & $1.439(2)$ & $\mathrm{C} 8-\mathrm{C} 9$ & $1.519(2)$ \\
$\mathrm{C} 9-\mathrm{O} 4$ & $1.437(2)$ & $\mathrm{C} 9-\mathrm{C} 10$ & $1.546(2)$ & $\mathrm{C} 10-\mathrm{C} 12$ & $1.526(2)$ \\
$\mathrm{C} 10-\mathrm{C} 13$ & $1.525(2)$ & $\mathrm{C} 10-\mathrm{C} 11$ & $1.535(2)$ & & \\
\hline
\end{tabular}

Table 5. Bond Angles in Compound 2027,

\begin{tabular}{|llllll|}
\hline O2-C1-O1 & $109.30(13)$ & O2-C1-C2 & $108.73(13)$ & O1-C1-C2 & $110.27(14)$ \\
O2-C1-C6 & $103.78(12)$ & O1-C1-C6 & $105.97(12)$ & C2-C1-C6 & $118.38(14)$ \\
C1-C2-C3 & $111.6(2)$ & C4-C3-C2 & $111.3(2)$ & C5-C4-C3 & $109.8(2)$ \\
O1-C5-C4 & $110.3(2)$ & C14-C6-C15 & $109.84(14)$ & C14-C6-C1 & $110.52(13)$ \\
C15-C6-C1 & $113.88(14)$ & C14-C6-C7 & $111.02(14)$ & C15-C6-C7 & $111.48(13)$ \\
C1-C6-C7 & $99.77(12)$ & O3-C7-C6 & $111.14(13)$ & O3-C7-C8 & $114.21(13)$ \\
C6-C7-C8 & $104.76(12)$ & O2-C8-C9 & $112.45(12)$ & O2-C8-C7 & $105.17(12)$ \\
C9-C8-C7 & $115.91(13)$ & O4-C9-C8 & $111.64(12)$ & O4-C9-C10 & $103.53(13)$ \\
C8-C9-C10 & $116.99(13)$ & C12-C10-C13 & $109.7(2)$ & C12-C10-C11 & $108.30(14)$ \\
C13-C10-C11 & $108.86(14)$ & C12-C10-C9 & $109.69(14)$ & C13-C10-C9 & $112.09(13)$ \\
C11-C10-C9 & $108.11(13)$ & C1-O1-C5 & $113.83(13)$ & C1-O2-C8 & $105.64(11)$ \\
\hline
\end{tabular}

